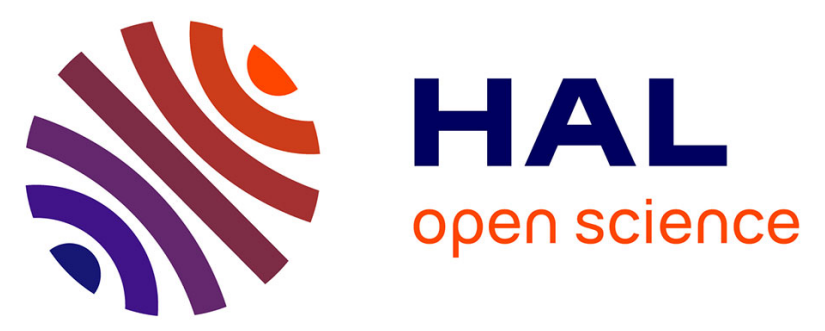

\title{
Denudation rates on cratonic landscapes: Comparison between suspended and dissolved fluxes, and 10Be analysis in the Nyong and Sanaga River basins, South Cameroon
}

Vincent Regard, Sébastien Carretier, Jean-Loup Boeglin, Jules-Rémy Ndam, Jean-Guy Dzana, Jean-Pierre Bedimo Bedimo, Jean Riotte, Jean-Jacques Braun

\section{- To cite this version:}

Vincent Regard, Sébastien Carretier, Jean-Loup Boeglin, Jules-Rémy Ndam, Jean-Guy Dzana, et al.. Denudation rates on cratonic landscapes: Comparison between suspended and dissolved fluxes, and 10Be analysis in the Nyong and Sanaga River basins, South Cameroon. 2016. hal-01286896

\author{
HAL Id: hal-01286896 \\ https://hal.science/hal-01286896 \\ Preprint submitted on 11 Mar 2016
}

HAL is a multi-disciplinary open access archive for the deposit and dissemination of scientific research documents, whether they are published or not. The documents may come from teaching and research institutions in France or abroad, or from public or private research centers.
L'archive ouverte pluridisciplinaire HAL, est destinée au dépôt et à la diffusion de documents scientifiques de niveau recherche, publiés ou non, émanant des établissements d'enseignement et de recherche français ou étrangers, des laboratoires publics ou privés. 


\title{
Denudation rates on cratonic landscapes: Comparison between suspended and dissolved fluxes, and ${ }^{10} \mathrm{Be}$ analysis in the Nyong and Sanaga River basins, South Cameroon
}

\author{
Vincent Regard*1,2,3, Sébastien Carretier ${ }^{3,1,2}$, Jean-Loup Boeglin ${ }^{1,2,3}$, Jules-Rémy \\ Ndam Ngoupayou ${ }^{4}$, Jean-Guy Dzana ${ }^{5}$, Jean-Pierre Bedimo Bedimo ${ }^{6}$, Jean Riotte ${ }^{1,2,3,7}$, \\ Jean-Jacques Braun ${ }^{1,2,3,6}$
}

1-Université de Toulouse ; UPS GET, 14 avenue E. Belin, F-31400 Toulouse, France

2- CNRS ; GET ; 14 avenue E. Belin, F-31400, Toulouse, France

3- IRD ; UR 234, GET ; 14 avenue E. Belin, F-31400, Toulouse, France

4- Department of Earth Sciences, University of Yaounde 1, P.O. Box 812, Yaounde, Cameroon

5- Department of Geography, University of Yaounde 1, P.O. Box 755, Yaounde, Cameroon

6- Institut de Recherches Géologiques et Minières/ Centre de Recherches Hydrologiques, BP 4110, Yaoundé (Cameroon)

7- LMI CEFIRSE. Indo-French Cell for Water Sciences, Indian Institute of Science, Bangalore 560012, India

Corresponding author Vincent.regard@get.obs-mip.fr

Manuscript accepted for publication in Earth Surface Processes and Landforms, March 2016

\begin{abstract}
South Cameroon is located in a tropical and tectonically quiescent region, with landscapes characterized by thick highly weathered regolith, indicative of the long term predominance of chemical weathering over erosion. Currently this region undergoes huge changes due to accelerated mutations related to a growing population and economical developments with associated needs and increasing pressures on land and natural resources. We analysed two of the main South Cameroon rivers: the Nyong River and Sanaga River. The Sanaga catchment undergoes a contrasted tropical climate from sub-humid mountainous and humid climate and is impacted by deforestation, agriculture, damming, mining and urbanization, especially in the Mbam sub-basin, draining the highly populated volcanic highlands. By contrast, the Nyong catchment, only under humid tropical climate, is preserved from anthropogenic disturbance with low population except in the region of Yaoundé (Méfou sub-basin). Moreover the Nyong basin is dam-free and less impacted by agriculture and logging.
\end{abstract}


We explore both denudation temporal variability and the ratio between chemical and physical denudation through two catchment-averaged erosion and denudation datasets. The first one consists of an 11-year long gauging dataset, while the second one comes from cosmogenic radionuclides $\left(\mathrm{CRN}\right.$, here $\left.{ }^{10} \mathrm{Be}\right)$ from sand sampled in the river mainstreams (time scale of tens to hundreds of thousands of years). Modern fluxes estimated from gauging data range from 5 to $100 \mathrm{~m} / \mathrm{Ma}$ (10 to $200 \mathrm{t} / \mathrm{km}^{2} / \mathrm{yr}$ ); our calculations indicate that the usual relative contribution of chemical vs physical denudation is $60 \%$ and $40 \%$, respectively, of the total denudation. ${ }^{10} \mathrm{Be}$ denudation rates and sediment fluxes range from 4.8 to $40.3 \mathrm{~m} / \mathrm{Ma}$ or 13 to $109 \mathrm{t} / \mathrm{km}^{2} / \mathrm{yr}$, respectively, after correction for quartz enrichment. These fluxes are slightly less than the modern fluxes observed in Cameroon and other stable tropical areas. The highest ${ }^{10} \mathrm{Be}$-derived fluxes and the highest physical vs. chemical denudation ratios are attributed to anthropogenic impact.

Keywords: Denudation rate; weathering; cosmogenic nuclides; Cameroon; craton

Running title: Denudation rates from modern fluxes and cosmogenic nuclides, Cameroon

\section{Introduction}

Erosion rates are strongly impacted by anthropogenic activities such as agriculture, damming, mining and urbanization. However, in order to appreciate the importance of these processes with regards to global erosion requires knowledge of the prehistoric, long term denudation rates imposed on land surfaces solely by natural processes (Wilkinson, 2005). Quantitative understanding of the variability in weathering and erosion fluxes on modern Earth is important for assessing soil resources and the impact of human activities (e.g., Balthazar et al., 2013; Bellin et al., 2013, 2011; Syvitski et al., 2005).

Continental tropical regions are often characterized by slow denudation in tectonically quiescent shield areas, which is the result of uplift and the base level likely due to eustatic changes such as those resulting from the advance and retreat of ice sheets in mid and boreal latitudes or from geodynamics (e.g., Conrad and Husson, 2009). Thus, in general, the balance between erosion and weathering, i.e., the weathering regime, has been in favour of deepening of the regolith through chemical weathering (towards kinetically limited regime), rather than by erosive stripping (e.g., Chadwick et al., 2013; Migoń and Lidmar-Bergström, 2001; Monod et al., Accepted; von Blanckenburg et al., 2015; de Oliveira Carmo and Vasconcelos, 2006). In addition, successive periods of laterization (usually leading to the formation of thick regolith and different generations of iron crust) have resulted from climate changes (Retallack, 2010; Tardy and Roquin, 1998).

Cosmogenic radionuclides (CRN), particularly ${ }^{10} \mathrm{Be}$, have been widely applied to assess the total denudation rates (i.e. the sum of the physical erosion and chemical weathering rates) over $10^{3}$ to $10^{6} \mathrm{yr}$ (e.g., Bierman et al., 1996; Brown et al., 1995; Carretier et al., 2013; Covault et al., 2013; Granger et al., 1996; Portenga and Bierman, 2011; Vanacker et al., 2007; von Blanckenburg, 2005). Recent attempts have been made to compare these long-term pre-anthropogenic denudation rates to modern physical erosion and chemical weathering rates. For instance, in the steep, humid 
tropical highlands of Sri Lanka, Hewawasam et al. (2003) showed that the short-term denudation rates (from river load gauging) exceed the total pre-anthropogenic denudation rates measured by cosmogenic nuclides by several orders of magnitude $(90-1400 \mathrm{~mm} / \mathrm{kyr}$ versus $10-20 \mathrm{~mm} / \mathrm{kyr})$. This study serves to highlight the severity of geomorphic change caused by human action. Other studies have shown lower shortterm denudation rate compared to long-term ${ }^{10} \mathrm{Be}$-derived denudation rates (e.g., Carretier et al., 2013; Kirchner et al., 2001; Schaller et al., 2001). This difference has been interpreted as reflecting the lack of low frequency large floods in the river load records or climate change. This can be illustrated with a recent example in the Blue Mountains Plateau in the western Sydney Basin, Australia, for which Tomkins et al. (2007) explored the role of extreme events (wildfires and catastrophic floods) in landscape denudation along a passive plate margin by determining the denudation rates for the short-term (contemporary) by river gauging, the medium-term (5-500 kyrs) with cosmogenic nuclides and long-term (1-100 Myrs) with apatite fission track thermochronology and post-basalt flow valley incision. They found that the average of the contemporary denudation rates is several times lower than the long-term average $(5.5 \pm 4 \mathrm{~mm} / \mathrm{kyr}$ versus $21.5 \pm 7 \mathrm{~mm} / \mathrm{kyr})$. They suggest that a plausible combination of infrequent mass movement events and high fluvial discharge could account for a significant proportion of the discrepancy between contemporary and long-term denudation rates. Using to a synthesis of the limited number of studies in the literature comparing short-term and medium term denudation rates, Covault et al. (2013, fig. 11) generalize this observation (larger medium-term denudation rates than short-term ones) up to a certain catchment size. For large catchments (equivalent sediment mass load >10 Mt/yr), gauging data tends to be similar to CRN data. According to these authors, this similarity could be due to a buffering effect in larger catchments, smoothing the high-frequency variations in sediment load. All these studies emphasize the need to better understand the temporal link between denudation rates impacted by climatic events and/or anthropogenic activities.

Another motivation underlined by the present paper deals with the relationship between physical erosion and chemical weathering fluxes in low relief areas. The role of erosion in enhancing the chemical weathering of silicate rocks in mountain ranges, a process that consumes atmospheric $\mathrm{CO}_{2}$ over geological timescales, has been the focus of an intense debate for the past two decades (e.g., Raymo et al., 1988; Willenbring and von Blanckenburg, 2010). Recent papers suggest that large peneplain surfaces may matter along with or more so than mountain ranges in terms of $\mathrm{CO}_{2}$ consumption (e.g., Carretier et al., 2014; Willenbring et al., 2013). However, there is a shortage of data on erosion and weathering fluxes in large cratonic regions in order to estimate their contribution to global silicate weathering (e.g., Gaillardet et al., 1999; Millot et al., 2002; West et al., 2005). This paper presents both fluxes in this type of region.

The present study focuses on the comparison of pre-anthropogenic and modern denudation rates in both the Sanaga and Nyong River basins, the main and adjacent river systems of South Cameroon flowing towards the Gulf of Guinea (Bird et al., 1994; Dubreuil et al., 1975; Olivry, 1986). Both basins, devoid of significant floodplains, are mainly developed on the silicate basements of the passive margin (South Cameroon Plateau). The Sanaga River basin experiences a contrasting tropical climate ranging from sub-humid mountainous to humid climates and is impacted by anthropogenic activities, mainly agriculture and damming. By contrast, the Nyong River basin, only 
under a humid tropical climate, is dam-free and less impacted by agriculture and logging.

The assessment of pre-anthropogenic denudation rates is based on an original dataset for cosmogenic radionuclides $\left({ }^{10} \mathrm{Be}\right)$ carried out on sandy sediments sampled in riverbeds. Modern physical erosion rates are assessed from river-gauged total suspended solids from 1968 to 1969 (Sanaga sensu stricto, Dubreuil et al., 1975), 1970 to 1971 (Mbam, Dubreuil et al., 1975) and 1995 to 1997 (Ndam Ngoupayou, 1997) for the Sanaga River and from the SO BVET database (http://bvet.omp.obsmip.fr/index.php) for the Nyong River and its tributaries (2000-2011).

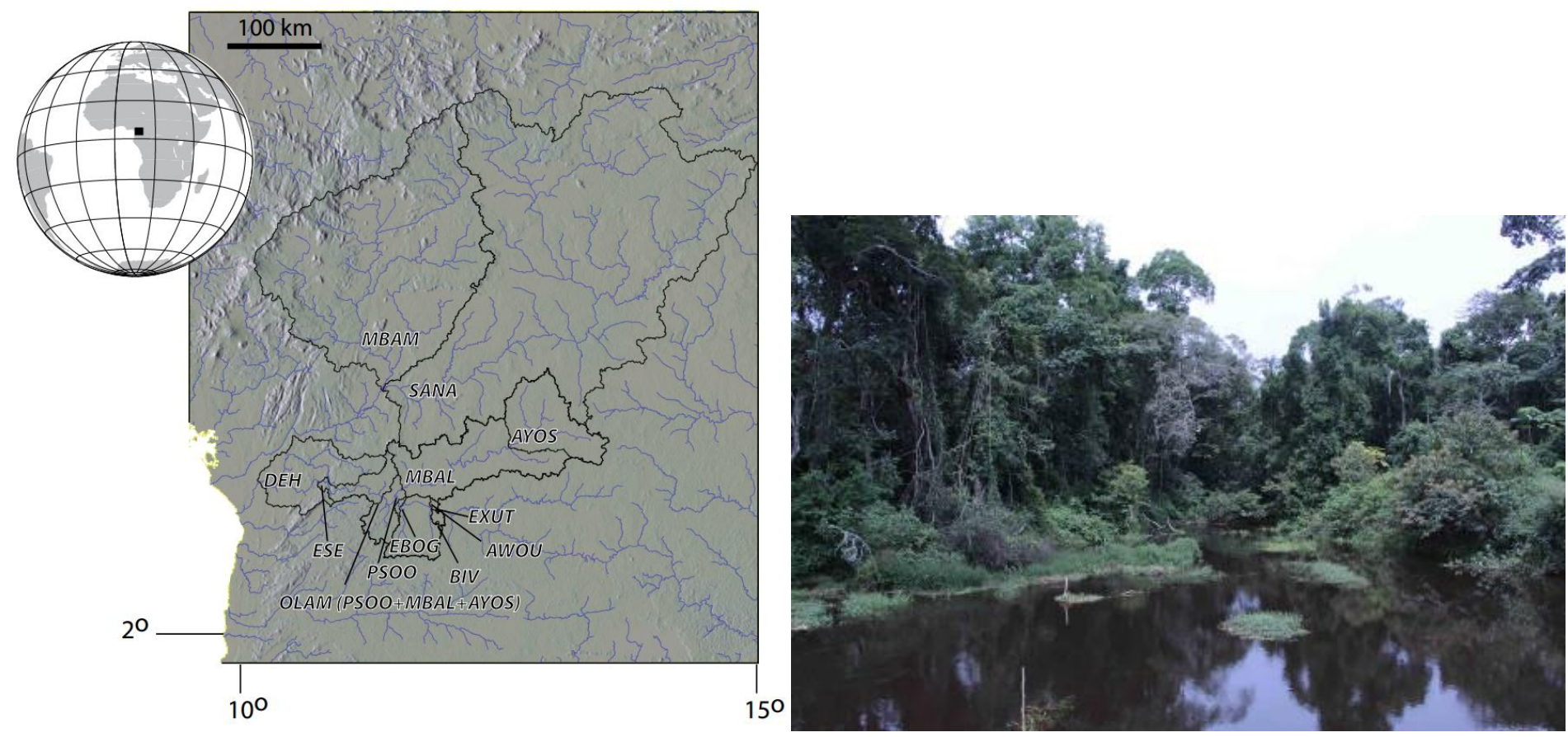

Figure 1. (Left) Study area shaded relief with the main stations and related catchments. Two rivers are investigated: the Sanaga divided into two tributaries, Sanaga (SANA) and Mbam (MBAM); and the Nyong river (AYOS, MBAL, BIV, AWOU, EXUT, EBOG, PSOO, OLAM, ESE and DEH). (Right, not present in published paper) Photograph of AWOU station.

\section{Settings}

The two main South Cameroon river basins are considered in this study: the Sanaga and Nyong River basins. The characteristics of the studied sub-basins (population density, climate, geomorphology, land use and land cover) are detailed in Table 1.

The Sanaga River basin $\left(135,000 \mathrm{~km}^{2}\right)$ stretches between latitudes $3^{\circ} 38^{\prime} \mathrm{N}$ and $7^{\circ} 22^{\prime}$ $\mathrm{N}$ and longitudes $9^{\circ} 38^{\prime} \mathrm{E}$ and $14^{\circ} 54^{\prime} \mathrm{E}$ and is the largest basin in Cameroon (Figure 1). The basin covers different climatic domains extending from a tropical climate with two seasons (mean annual rainfall, MAR, from 1500 to $1900 \mathrm{~mm} / \mathrm{yr}$ ) in the north and northwest, to an equatorial climate with four seasons (MAR from 1600 to $2500 \mathrm{~mm} / \mathrm{yr}$ ) in the south and southwest (Figure 1). In a large part of its basin, the Sanaga River drains the South Cameroon Plateau (650-850 m a.s.I.), a vast undulating landscape locally interrupted by inselbergs with successive steps at fault traces and mostly covered by thick mature lateritic regolith mainly developed on a granito-gneissic 
basement (Ségalen, 1967). The South Cameroon Plateau is referred to as a Miocene lower planation surface (Guillocheau et al., 2015). It is bordered to the north and west by the Cameroonian Ridge, which is composed of a succession of high plateaus and volcanic massifs. This ridge can be subdivided into two very distinct regions: the Adamawa Plateau and the Western Highlands. These topographic units are composed of a Precambrian basement (comprising $89 \%$ plutonic and metamorphic rocks), which in places is covered by recent eruptive volcanic rocks and sedimentary formations (Regnoult, 1986).

\begin{tabular}{|c|c|c|c|c|c|c|c|}
\hline River basin & $\begin{array}{c}\text { Area } \\
\left(\mathbf{k m}^{2}\right)\end{array}$ & $\begin{array}{l}\text { Tropical } \\
\text { climate }\end{array}$ & $\begin{array}{c}\text { Geomorphological units } \\
\text { and geology }\end{array}$ & $\begin{array}{c}\text { Population density } \\
\left(\text { inh } / \mathbf{k m}^{2}\right)\end{array}$ & Land cover & Land use & Dams \\
\hline $\begin{array}{l}\text { Sanaga } \\
\text { (at Ebebda } \\
\text { bridge) }\end{array}$ & $\begin{array}{l}76000 \\
(56 \% \text { of } \\
\text { the whole } \\
\text { basin) }\end{array}$ & $\begin{array}{l}\text { Sub-humid } \\
\text { (North-East) } \\
\text { to } \\
\text { Humid } \\
\text { (South- } \\
\text { West) }\end{array}$ & $\begin{array}{l}\text { South Cameroon plateau (650-850 } \\
\mathrm{m} \text { a s } \mathrm{l} \text { ) } \\
\text { Adamawa ridge ( } 1100 \mathrm{~m} \text { a.s. } \mathrm{l} \text { ) } \\
\text { Granito-gneissic basement with less } \\
\text { abundant mafic to ultramafic rocks } \\
\text { Thick lateritic regolith (up to } 50 \mathrm{~m} \\
\text { deep) }\end{array}$ & $\begin{array}{l}\text { - 50-100 } \\
\text { Agro-industrial zones } \\
\text { (e. g. Mbandjeck): } \\
\text { : 1-10 } \\
\text { Rural zones }\end{array}$ & $\begin{array}{l}\text {-Savannah } \\
\text { - Transitional forest- } \\
\text { savannah } \\
\text {-Semi-decideous } \\
\text { and evergreen } \\
\text { tropical forest }\end{array}$ & $\begin{array}{l}\text { - Agriculture (subsistence and } \\
\text { industrial), } \\
\text { - Production activities consisting } \\
\text { mainly of animal husbandry and } \\
\text { forestry exploitation }\end{array}$ & $\begin{array}{l}\text { - Mbakaou } \\
\text { filled up: } 1969 \\
2.6 \times 10^{9} \mathrm{~m}^{3} \\
\text { - Lom-Pangar } \\
\text { filled up: } 2015 \\
6 \times 10^{9} \mathrm{~m}^{3}\end{array}$ \\
\hline $\begin{array}{l}\text { Mbam } \\
\text { (at Ebebda } \\
\text { bridge) }\end{array}$ & $\begin{array}{l}\mathbf{4 2 0 0 0} \\
(31 \% \text { of } \\
\text { the whole } \\
\text { basin) }\end{array}$ & $\begin{array}{l}\text { Sub-humid } \\
\text { to } \\
\text { Humid }\end{array}$ & $\begin{array}{l}\text { Western Highlands, } \\
\text { (1000-1600 m a s } 1) \\
\text { Granito-gneissic basement } \\
\text { in places, covered, by recent } \\
\text { eruptive volcanic rocks and } \\
\text { sedimentary formations } \\
\text { Thick lateritic regolith, highly fertile } \\
\text { soils on volcanics. }\end{array}$ & $\begin{array}{l}\text { - } 100-200 \\
\text { Rural zones } \\
\text { - up to } 3800: \text { main } \\
\text { Urban centres } \\
\text { (Bafoussam, } \\
\text { Bamenda, Eroumban) }\end{array}$ & $\begin{array}{l}\text {-Savannah } \\
\text { - Transitional forest- } \\
\text { savannah } \\
\text {-Semi-decideous } \\
\text { and evergreen } \\
\text { tropical forest }\end{array}$ & $\begin{array}{l}\text { - Main vegetable-producing } \\
\text { region in the country } \\
\text { - Cattle rearing }\end{array}$ & $\begin{array}{l}\text { - Bamendjin: } \\
\text { filled up: } 1974 \\
1.8 \times 10^{9} \mathrm{~m}^{3} \\
\text { - Mape } \\
\text { filled up: } 1988 \\
3.3 \times 10^{9} \mathrm{~m}^{3}\end{array}$ \\
\hline $\begin{array}{l}\text { Nyong } \\
\text { (nested } \\
\text { watershed } \\
\text { network) }\end{array}$ & 27800 & $\begin{array}{l}\text { Humid to } \\
\text { equatorial }\end{array}$ & $\begin{array}{l}\text { South Cameroon Plateau (650-850 } \\
\mathrm{m} \text { a s } \mathrm{l} \text { ) } \\
\text { Coastal plain ( } 0-300 \mathrm{~m} \text { a s } \mathrm{L} \text { ) } \\
\text { Granito-gneissic basement with less } \\
\text { abundant mafic to ultramafic rocks } \\
\text { Thick lateritic regolith }\end{array}$ & $\begin{array}{l}\text { - 5-10 } \\
\text { Rural zones } \\
\text { - up to } 16000 \\
\text { Urban zone of } \\
\text { Yaoundé }\end{array}$ & $\begin{array}{l}\text {-Semi-decideous } \\
\text { and evergreen } \\
\text { tropical forest }\end{array}$ & $\begin{array}{l}\text { - Agroforestry (slash and burn } \\
\text { practices, palmtree plantations, } \\
\text {..) } \\
\text { - Logging }\end{array}$ & - Dam-free \\
\hline
\end{tabular}

MAR: mean annual rainfall

Table 1. Settings of the different studied basins.

Two large sub-basins of the Sanaga River basin are considered in this study above the Ebebda Bridge: the upper Sanaga River basin sensu stricto and the Mbam River basin (Figure 1, Table 1).

The Nyong River basin $\left(27800 \mathrm{~km}^{2}\right)$ lies between latitudes $2^{\circ} 48^{\prime} \mathrm{N}$ and $4^{\circ} 32^{\prime} \mathrm{N}$ and longitudes $9^{\circ} 54^{\prime} \mathrm{E}$ and $13^{\circ} 30^{\prime} \mathrm{E}$. The Nyong River flows in the low-relief South Cameroon Plateau landscape and then joins the coastal plain by a series of falls corresponding to the scarp of the passive margin. The basement of the Nyong River basin is mostly silicates, composed of dominant granito-gneiss (Precambrian and Panafrican in age) intermingled with less abundant mafic to ultramafic rocks from Precambrian greenstone belts (Regnoult, 1986). The seasonal rainfall variations exhibit a typical bimodal distribution with MAR values between 1600 and $1800 \mathrm{~mm} / \mathrm{yr}$. The basin is entirely located in the tropical rainforest zone developed on deep mature lateritic regolith (reaching up to $50 \mathrm{~m}$ on the plateau) and hydromorphic soils in the valleys. The Upper Nyong basin is covered by semi-deciduous forest characterized by Stertuliaceae and Ulmaceae. Marsh forest and water meadows are found and raffias (Raphia montbuttorum) grow in the swampy depressed zones (Santoir and Bopda, 1995) for $150 \mathrm{~km}$ upstream of the Upper Nyong basin. Downstream (westwards), the climate passes progressively to an equatorial monsoon climate $(2000-3000 \mathrm{~mm}$ of rainfall). The climatic transition leads to a change in vegetation cover from semi- 
deciduous forest to the east to littoral forest (Lophira alata) to the west, passing by evergreen forest (Caesalpinaceae) in-between.

In the whole basin, the vegetation cover is significantly damaged by agroforestry, logging, and slash and burn practices. Human activities include moderate industrial forestry, traditional shifting cultivation (manioc and other tubers, banana, corn, peanuts, cocoa beans and tomatoes) without significant fertilizer inputs. The Nyong River is dam-free.

The Nyong River basin has been monitored since the 60's, but unfortunately not continuously (Olivry, 1986). Since 2001, a nested network of monitored stations has been set up on the Upper Nyong basin within the framework of the SO BVET project. It encompasses five hydrological stations in the So'o basin, a southern tributary of the Nyong River. These are, from upstream to downstream: Nsimi at the outlet of the small experimental Mengong watershed (14 km from Zoétélé, $120 \mathrm{~km}$ SSE from Yaoundé), Messam on the Awout stream, Pont So'o on the So'o River, Mbalmayo and Olama on the Nyong Rivers; water from the So'o Basin mix upstream from Olama with the water coming from the eastern Upper Nyong basin flowing into Mbalmayo (Erreur ! Source du renvoi introuvable.).

\section{Sampling and methodology}

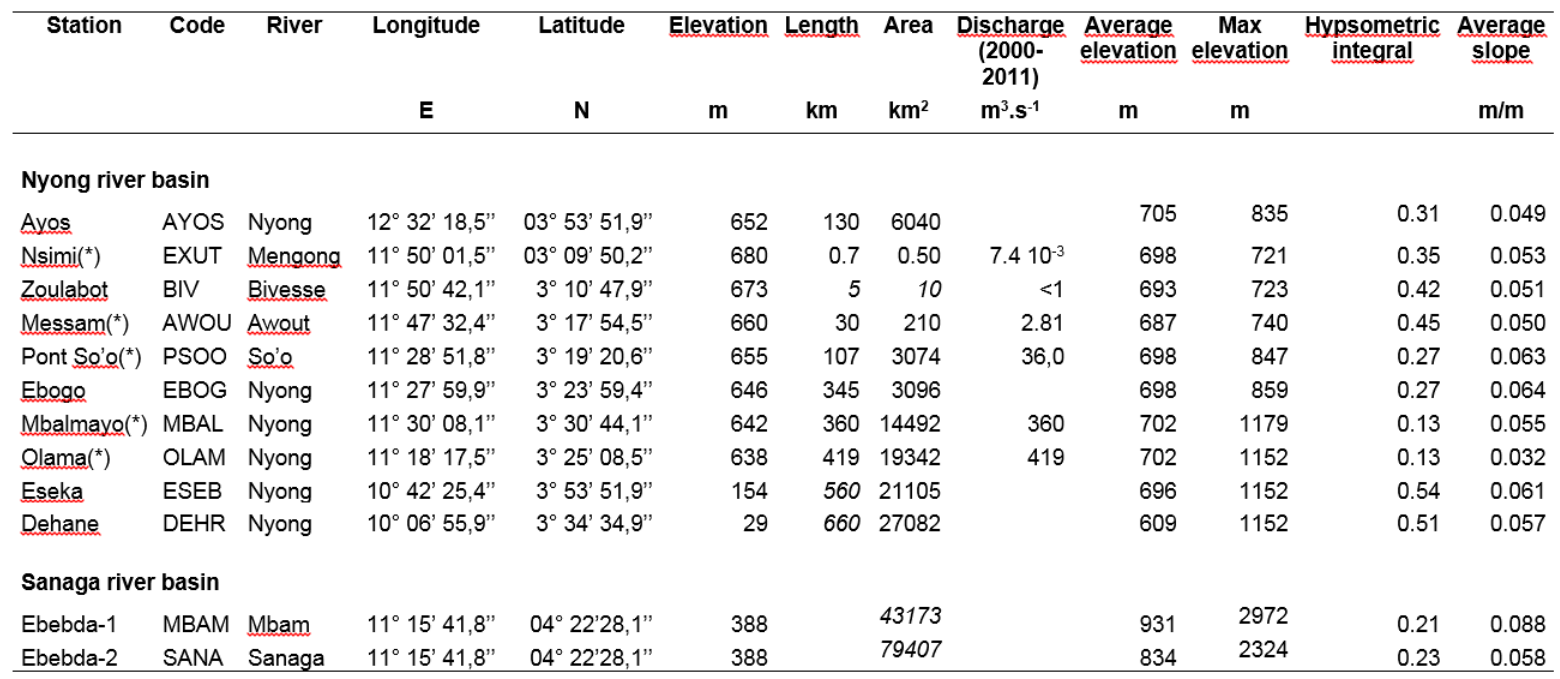

(*) SO BVET sites

Italic: estimated

Table 2. Gauging/sampling station and corresponding catchment characteristics. Asterisks denote SO BVET sites and italics estimated values.

\subsection{Historical gauging stations for the Sanaga and Nyong River basins}

The monitoring stations for the Sanaga River basin were set up by ORSTOM (now IRD) in partnership with the Centre de Recherches Hydrologiques of IRGM, Yaoundé, Cameroon. The Sanaga sensu stricto and Mbam Rivers have been monitored for discharge since the early 50's. The former stations at the outlet of the basins were located at Nachtigal for the Sanaga River sensu stricto and at Goura for the Mbam River (Dubreuil et al., 1975). For the Sanaga River sensu stricto the first TSS dataset is available for the years 1968 and 1969 before the Mbakaou dam was constructed. 
For the Mbam River the water years 1970-1971 and 1971-1972 are recorded before Bamendjin and the Mape fillings. For the Nyong River, a nested watershed network from 0.5 to $27000 \mathrm{~km}^{2}$ was sampled during the 2000-2011 period (Table 2).

\subsection{Total Suspended Solids (TSS) and Total Dissolved Solids (TDS) for the Nyong River basin}

The data presented in this study are from the SO BVET stations for the years 20002011 (Table 3).

\begin{tabular}{|c|c|c|c|c|c|c|c|c|c|c|c|c|c|c|c|c|c|c|}
\hline & & $\begin{array}{l}\text { temp. } \\
{ }^{\circ} \mathrm{C}\end{array}$ & $\mathrm{pH}$ & $\begin{array}{r}\text { E.C. } \\
\mu \mathrm{S} / \mathrm{cm}\end{array}$ & $\begin{array}{c}\mathrm{Na}^{+} \\
\mu \mathrm{mol} / \mathrm{L}\end{array}$ & $\begin{array}{r}\mathrm{K}^{+} \\
\mu \mathrm{mol} / \mathrm{L}\end{array}$ & $\begin{array}{c}\mathrm{Mg}^{2+} \\
\mu \mathrm{mol} / \mathrm{L}\end{array}$ & $\begin{array}{r}\mathrm{Ca}^{2+} \\
\mu \mathrm{mol} / \mathrm{L}\end{array}$ & $\begin{array}{r}\mathrm{TZ+} \\
\mu \mathrm{mol} / \mathrm{L}\end{array}$ & $\begin{array}{r}\mathrm{Cl}^{-} \\
\mu \mathrm{mol} / \mathrm{L}\end{array}$ & $\begin{array}{r}\mathrm{NO}_{3}^{-} \\
\mu \mathrm{mol} / \mathrm{L}\end{array}$ & $\begin{array}{r}\mathrm{SO}_{4}{ }^{2-} \\
\mu \mathrm{mol} / \mathrm{L}\end{array}$ & $\begin{array}{r}\mathrm{HCO}_{3}^{-} \\
\mu \mathrm{mol} / \mathrm{L}\end{array}$ & $\begin{array}{r}\mathrm{TZ}- \\
\mu \mathrm{mol} / \mathrm{L}\end{array}$ & $\begin{array}{r}\mathrm{SiO}_{2} \\
\mu \mathrm{mol} / \mathrm{L}\end{array}$ & $\begin{array}{c}\mathrm{DOC} \\
\mathrm{mg} / \mathrm{L}\end{array}$ & $\begin{array}{c}\text { TDS } \\
\mathrm{mg} / \mathrm{L}\end{array}$ & $\begin{array}{c}\text { TSS } \\
\mathrm{mg} / \mathrm{L}\end{array}$ \\
\hline \multicolumn{19}{|c|}{ Spring of Mengong at Nsimi, $Q m=0.73 \mathrm{~L} / \mathrm{s}$} \\
\hline mean & & 24.1 & 4.54 & 12.5 & 29 & 4.92 & 12.3 & 9.75 & 78.7 & 11.2 & 9.29 & $<1$ & 59.3 & 80.8 & 89.6 & 0.31 & 11.6 & - \\
\hline$\pm \sigma$ & & 1.0 & - & 0.9 & 6.1 & 2.6 & 1.2 & 0.9 & 10.0 & 1.6 & 3.5 & - & 10.2 & 10.0 & 7.7 & 0.3 & 1.2 & - \\
\hline vwm & & 24.1 & 4.54 & 12.5 & 29.2 & 4.87 & 12.3 & 9.79 & 79.1 & 11.2 & 9.07 & $<1$ & 59.8 & 81.2 & 90.2 & 0.3 & 11.6 & - \\
\hline flux & $\mathrm{kg} / \mathrm{yr}$ & - & - & - & 15.1 & 4.17 & 6.86 & 8.97 & 35.1 & 8.93 & 12.7 & $<1.5$ & 82.8 & 106 & 123 & 6.75 & 264 & - \\
\hline sp. flux & $\mathrm{kg} / \mathrm{km}^{2} / \mathrm{yr}$ & - & - & - & & - & - & - & - & - & - & - & - & - & - & - & - & - \\
\hline \multicolumn{19}{|c|}{ Outlet of Mengong at Nsimi, $Q m=7.36 \mathrm{~L} / \mathrm{s}, \mathrm{S}=0.60 \mathrm{~km}^{2}$} \\
\hline mean & & 24.2 & 5.21 & 16.6 & 54.5 & 6.59 & 23.8 & 32.8 & 175 & 7.45 & $<1$ & $\sim 2.1$ & 72.6 & $\sim 85.5$ & 135 & 14.3 & 16.5 & 8.07 \\
\hline$\pm \sigma$ & & 1.34 & - & 2.92 & 13.2 & 3.06 & 4.78 & 6.38 & 36.8 & 4.44 & - & $\sim 4.3$ & 18.5 & $\sim 22.4$ & 8.3 & 3.24 & 2.04 & 2.78 \\
\hline vwM & & 23.8 & 5.06 & 15.7 & 47.4 & 7 & 21.8 & 30.7 & 160 & 7.96 & $<1$ & $\sim 1.4$ & 60.1 & $\sim 72.0$ & 135 & 14.6 & 15.4 & 7.46 \\
\hline flux & $\mathrm{kg} / \mathrm{yr}$ & - & - & - & 259 & 63.5 & 125 & 290 & 738 & 65.4 & $<10$ & $\sim 35$ & 872 & $\sim 980$ & 1882 & 3406 & 3600 & 1724 \\
\hline sp. flux & $\mathrm{kg} / \mathrm{km}^{2} / \mathrm{yr}$ & - & - & - & 431 & 106 & 208 & 483 & 1230 & 109 & $<17$ & $\sim 58$ & 1453 & $\sim 1633$ & 3137 & 5677 & 6000 & 2873 \\
\hline \multicolumn{19}{|c|}{ Awout at Messam station, $Q m=2.81 \mathrm{~m}^{3} / \mathrm{s}, \mathrm{S}=206 \mathrm{~km}^{2}$} \\
\hline mean & & 23.1 & 4.73 & 23 & 50.5 & 32.2 & 30.6 & 49.7 & 246 & 19.8 & $\sim 0.9$ & 8.18 & 55.4 & 92.2 & 178 & 22.9 & 20.8 & 13.9 \\
\hline$\pm \sigma$ & & 1.34 & - & 8.36 & 13.7 & 27.2 & 12.7 & 18.7 & $98 . .4$ & 16.3 & $\sim 1.4$ & 16.6 & 40.8 & 67.8 & 40.2 & 4.47 & 7.72 & 8.41 \\
\hline vwM & & 22.5 & 4.71 & 20.5 & 41 & 24.9 & 26 & 43.2 & 208 & 15.5 & $\sim 0.5$ & 4.03 & 38.5 & 62.3 & 145 & 22.3 & 16.3 & 9.6 \\
\hline flux & $\mathrm{t} / \mathrm{yr}$ & - & - & - & 81.9 & 80.9 & 54 & 148 & 365 & 45.8 & $\sim 2.9$ & 31.8 & 208 & 289 & 807 & 1917 & 1460 & 847 \\
\hline sp. flux & $\mathrm{kg} / \mathrm{km}^{2} / \mathrm{yr}$ & - & - & - & 398 & 393 & 262 & 717 & 1772 & 222 & $\sim 14$ & 154 & 1009 & 1401 & 3916 & 9304 & 7087 & 4112 \\
\hline \multicolumn{19}{|c|}{ So'o at Pont So'o station, $Q m=36.0 \mathrm{~m}^{3} / \mathrm{s}, \mathrm{S}=3,070 \mathrm{~km}^{2}$} \\
\hline mean & & 24.8 & 5.49 & 23.9 & 57.7 & 24.8 & 32 & 47 & 241 & 17.6 & $\sim 1.5$ & 9.44 & 100 & 139 & 176 & 15.1 & 23.3 & 20.5 \\
\hline$\pm \sigma$ & & 2.19 & - & 7.94 & 12.7 & 10.8 & 8.27 & 10.5 & 57.8 & 9.31 & $\sim 3.3$ & 10.2 & 50.8 & 73.8 & 14 & 3.39 & 5.96 & 5.67 \\
\hline vWM & & 23.5 & 5.36 & 20.3 & 47.8 & 21.9 & 27.4 & 41.8 & 209 & 15.6 & $\sim 0.7$ & 5.14 & 69.6 & 97.3 & 164 & 17.1 & 19.5 & 18.9 \\
\hline flux & t/yr & - & - & - & 1241 & 967 & 753 & 1892 & 4854 & 618 & $\sim 50$ & 552 & 4809 & 6029 & 11158 & 19386 & 22026 & 21386 \\
\hline sp. flux & $\mathrm{kg} / \mathrm{km}^{2} / \mathrm{yr}$ & - & - & - & 404 & 315 & 245 & 616 & 1581 & 201 & $\sim 16$ & 180 & 1567 & 1964 & 3635 & 6315 & 7175 & 6966 \\
\hline \multicolumn{19}{|c|}{ Nyong river at Mbalmayo station, $Q \mathrm{~m}=110.4 \mathrm{~m}^{3} / \mathrm{s}, \mathrm{S}=13,555 \mathrm{~km}^{2}$} \\
\hline mean & & 26.4 & 5.73 & 30.4 & 70.7 & 35.7 & 36.5 & 56.2 & 292 & 42.9 & $\sim 3.0$ & 8.17 & 126 & 188 & 132 & 15.9 & 24.3 & 12.8 \\
\hline$\pm \sigma$ & & 2.05 & - & 11.4 & 38.9 & 19 & 7.51 & 17.7 & 105 & 28 & $\sim 5.1$ & 8.93 & 83.3 & 126 & 17.4 & 5.15 & 9.83 & 3.96 \\
\hline vWM & & 25.5 & 5.61 & 25.3 & 47.3 & 29.2 & 32.9 & 47.1 & 237 & 29.8 & $\sim 1.1$ & 4.3 & 84.1 & 124 & 127 & 18.2 & 19.2 & 12.6 \\
\hline flux & t/yr & - & - & - & 3838 & 4047 & 2797 & 6630 & 17315 & 3777 & $\sim 236$ & 1512 & 18158 & 23683 & 26730 & 63306 & 67720 & 43883 \\
\hline sp. flux & $\mathbf{k g} / \mathbf{k m}^{2} / \mathbf{y r}$ & - & - & - & 283 & 299 & 206 & 489 & 1277 & 279 & $\sim 17$ & 112 & 1340 & 1747 & 1972 & 4670 & 4996 & 3237 \\
\hline \multicolumn{19}{|c|}{ Nyong river at Qlama station, $Q m=166.2 \mathrm{~m}^{3} / \mathrm{s}, \mathrm{S}=18,510 \mathrm{~km}^{2}$} \\
\hline mean & & 26.5 & 5.54 & 25.9 & 61.2 & 30.1 & 33.2 & 50.5 & 259 & 31 & $\sim 2.5$ & 7.83 & 105 & 154 & 138 & 15.6 & 22.1 & 14.3 \\
\hline$\pm \sigma$ & & 2.4 & - & 6.43 & 24.1 & 12.2 & 4.34 & 9.11 & 59.5 & 13.8 & $\sim 3.9$ & 7.6 & 48.2 & 75.9 & 136 & 4.02 & 5.71 & 4.59 \\
\hline VWM & & 25.3 & 5.39 & 23.5 & 48.2 & 27.7 & 31.6 & 46.4 & 233 & 26 & $\sim 3.8$ & 4.76 & 83.4 & 122 & 136 & 17.2 & 19.7 & 15.8 \\
\hline flux & t/yr & - & - & - & 5831 & 5708 & 4028 & 9755 & 25326 & 4869 & 1219 & 2424 & 26791 & 35303 & 43201 & 89752 & 103830 & 83079 \\
\hline sp. flux & $\mathbf{k g} / \mathbf{k m}^{2} / \mathbf{y r}$ & - & - & - & 315 & 308 & 218 & 527 & 1368 & 263 & $\sim 66$ & 131 & 1447 & 1907 & 2334 & 4849 & 5609 & 4488 \\
\hline
\end{tabular}

Table 3. Water characteristics for the Nyong catchment stations from monthly sampling during 1998/99 cyclex: Temperature (temp.) is in ${ }^{\circ} \mathrm{C}$, electric conductivity (E.C.) in $\mu \mathrm{S} / \mathrm{cm}$; major cations and anions, as well as dissolved silica concentrations, are in $\mu \mathrm{mol} / \mathrm{L}$; sum of cations (SCat, including protons) and sum of anions (SAn) in $\mu \mathrm{eq} / \mathrm{L}$; dissolved organic carbon (DOC), total of mineral dissolved species (TDS) and total of suspended solids (TSS) concentrations are in $\mathrm{mg} / \mathrm{L}$; given $\mathrm{pH}$ values correspond to field measurements, but for the calculation of SCat, SAn and bicarbonate concentrations, $\mathrm{pH}$ values determined at the laboratory were used; the arithmetic mean (mean), standard deviation $( \pm \sigma)$ and discharge-weighted mean (DWM) are given for most parameters; fluxes are expressed in t/yr (except at spring and outlet of Mengong, in $\mathrm{kg} / \mathrm{yr}$ ), specific fluxes are in $\mathrm{kg} / \mathrm{km}^{2} / \mathrm{yr}$. 
Discharge is determined from the daily-measured water stages by local observers on limnimetric scales (staff gauges), using calibration curves drawn from a gauging dataset for each station (Table 2 and http://bvet.obsmip.fr/en/stations/cameroon/meteo-nyong).

Bi-monthly (or higher frequency) water samples were collected between $30-50 \mathrm{~cm}$ below the water surface, preferentially where the flow velocity was high enough to allow for a good homogenization of the solid particles of different sizes. In fact, for the large streams of the tropical zone of Africa, including those of Cameroon, the sampling technique along one vertical which is rather simple, fast and practical, gives results that are satisfactory and relatively close to those of the full solid gauging method (e.g., Lienou et al., 2005; Ndam Ngoupayou et al., 2014; Olivry et al., 1988)

The water samples were filtered on-site with cellulose acetate $0.45 \mu \mathrm{m}$ membranes using a polycarbonate Millipore filtration unit of $500 \mathrm{~mL}$. The filters are pre-dried $\left(60^{\circ} \mathrm{C}\right)$ and weighted before the filtration procedure in order to determine the TSS. The particulate fractions retained on the filters is obtained by weighting the filter on a Mettler type balance (precision of $0.1 \mathrm{mg}$ ) and dried in the oven at $105^{\circ} \mathrm{C}$, after desiccation. The estimation of the instantaneous TSS concentration is obtained from the difference in weight between the loaded filter and the filter before filtration for the volume of water brought up to $10^{3} \mathrm{~mL}$. For this procedure, Maneux (1998) calculated a theoretical error of $5 \%$, when the suspended sediment concentration is less than or equal to $10 \mathrm{mg} \mathrm{L}^{-1}$ and $3 \%$ when it is more than $10 \mathrm{mg} \mathrm{L}^{-1}$.

TDS is calculated after the following procedure. The filtered water is stored in acid washed Nalgene $\AA$ polypropylene bottles, either acidified with ultrapure $15 \mathrm{~N} \mathrm{HNO}_{3}$ for the major cation analyses or non-acidified for the major anion analyses. Conductivity, $\mathrm{pH}$, and water temperature measurements were taken out on-site. Major cations $(\mathrm{Ca}$, $\mathrm{Mg}, \mathrm{K}, \mathrm{Na}$ ) and anions $\left(\mathrm{Cl}, \mathrm{SO}_{4}, \mathrm{NO}_{3}\right)$ were determined by lon Chromatography at Geoscience Environnement Toulouse (GET) (Table 3). The typical uncertainty was 5\% and the detection limit ranged up to $1 \mu \mathrm{mol} / \mathrm{L}$. Alkalinity is determined by titration with $\mathrm{HNO}_{3}$ and the Gran method (Gran, 1952). The typical uncertainty was $5 \%$ and detection limit ranged up to $1 \mu \mathrm{mol} / \mathrm{L}$. Aqueous silica concentrations were measured both by standard colorimetry (molybdate blue method) and ICP-MS. The usual incertitude was $5 \%$ and the detection limit approached $1 \mu \mathrm{mol} / \mathrm{L}$. The international standard SLRS-3 was used as a reference.

The Volume Weighted Mean (VWM) of the TDS and TSS concentrations was calculated using Equation 1.

$$
\text { Equation } 1 \quad V W M=\sum_{i=1}^{n} C_{i} V_{i} / \sum_{i=1}^{n} V_{i}
$$

The same equation is used to calculate the TDS and TSS VWM concentrations in the stream water, where $C_{i}$ is the concentration of an instantaneous stream flow $i$ and $V_{i}$ is the discharge volume $(L)$ for the period between two samplings; the denominator is the whole sampling period discharge. The TDS and TSS values are remarkably constant in the studied river systems with only $20 \%$ fluctuation over the sampling period, therefore the dependence of the concentrations on discharge is weak. Moreover, because of the long monitoring duration, the water sampling encompassed 
some of the highest discharge conditions, such that high magnitude events were properly sampled for the monitoring period.

\subsection{Pre-anthropogenic denudation rates with ${ }^{10} \mathrm{Be}$ analyses}

For the Sanaga sensu stricto and Mbam River basins, the sandbar sediments for cosmogenic analysis were collected at Ebebda, at the confluence of both rivers.

For the Nyong River basin, eight sampling sites were selected in the upper basin (on the South Cameroon Plateau) and two in the lower basin. On the South Cameroon Plateau, the sites encompass (i) the five stations of the SO-BVET project (Mengong at Nsimi, Awout at Messam, So'o at Pont-So'o, Nyong at Mbalmayo and Olama) and (ii) three additional stations (Bivesse at Zoulabot, Nyong at Ayos and Ebogo). The sampling sites downstream the escarpment of the passive margin encompass the Eseka and Dehane stations on the lower Nyong River. For the Zoulabot, Eseka and Dehane sites, two sand samples have been collected corresponding to different sandbars.

Sample preparation for the ${ }^{10} \mathrm{Be}$ analyses was carried out at Geosciences Environnement Toulouse (GET) using the procedure described by Von Blanckenburg et al. (1996). Samples were sieved into the 0.5-1 $\mathrm{mm}$ fraction. After chemical leaching with $\mathrm{HCl}$ and $\mathrm{H}_{2} \mathrm{SiF}_{6}$, the samples were etched in $\mathrm{HF}$. A Be carrier $(0.3 \mathrm{~g}$ of low noise carrier from A. Alimanovic, University of Melbourne, $1155 \mathrm{ppm},{ }^{10} \mathrm{Be} /{ }^{9} \mathrm{Be}<10^{-15}$ ) was added to the samples before complete dissolution in HF. Beryllium was extracted using chromatography as described in von Blanckenburg et al. (1996). Measured ${ }^{10} \mathrm{Be}$ ratios were corrected using blanks that were processed similarly to the samples. Finally, sample oxidation and targets were prepared and measured with the CEREGE LN2C and ASTER AMS facility (Table 4).

\begin{tabular}{|c|c|c|c|c|c|c|c|c|c|}
\hline Station & Code & River & $\begin{array}{c}\text { Mass } \\
\text { Quartz } \\
\text { g }\end{array}$ & $\begin{array}{c}\text { Carrier } \\
\mu g\end{array}$ & $\mathbf{N}^{10} \mathrm{Be}$ & ${ }^{10} \mathrm{Be} /{ }^{9} \mathrm{Be}$ & $\begin{array}{c}\text { uncertainty } \\
\text { measure+standard } \\
\%\end{array}$ & $\begin{array}{c}{\left[{ }^{10} \mathrm{Be}\right]} \\
10^{\wedge} 3 \mathrm{at} / \mathrm{g}\end{array}$ & $+1-$ \\
\hline Process blank & & & 0.00 & 308 & 9 & $1.33 E-15$ & 33.49 & & \\
\hline \multicolumn{10}{|c|}{ Nyong river basin } \\
\hline Ayos & AYOS & Nyong & 40.08 & 308 & 1543 & $1.99 \mathrm{E}-12$ & 4.20 & 1178 & 49 \\
\hline Nsimi $\left({ }^{*}\right)$ & EXUT & Mengong & 47.74 & 308 & 2807 & $2.92 \mathrm{E}-12$ & 3.77 & 1454 & 55 \\
\hline Zoulabot-1 & BIVB & Bivesse & 41.38 & 310 & 3590 & $3.26 \mathrm{E}-12$ & 3.67 & 1887 & 69 \\
\hline Zoulabot-2 & BIVG & " & 48.96 & 307 & 3096 & $3.49 \mathrm{E}-12$ & 3.75 & 1694 & 63 \\
\hline Messam $\left({ }^{\star}\right)$ & AWOU & Awout & 49.68 & 308 & 3026 & $3.11 \mathrm{E}-12$ & 3.81 & 1490 & 57 \\
\hline Pont So'o( $\left.{ }^{*}\right)$ & PSOO & So'o & 31.87 & 308 & 1402 & $1.57 \mathrm{E}-12$ & 4.22 & 1175 & 50 \\
\hline Ebogo & EBOG & Nyong & 36.98 & 309 & 1236 & 1.27E-12 & 4.40 & 818 & 36 \\
\hline Mbalmayo $\left.{ }^{\star}\right)$ & MBAL & $"$ & 41.59 & 308 & 1014 & $1.33 \mathrm{E}-12$ & 4.53 & 761 & 34 \\
\hline Olama(*) & OLAM & $"$ & 45.18 & 308 & 1272 & $1.66 \mathrm{E}-12$ & 4.44 & 872 & 39 \\
\hline Eseka-1 & ESEB & $"$ & 44.35 & 309 & 1223 & $1.22 \mathrm{E}-12$ & 4.49 & 654 & 29 \\
\hline Eseka-2 & ESEJ & $"$ & 52.57 & 307 & 1250 & 1.15E-12 & 4.32 & 520 & 22 \\
\hline Dehane-1 & DEHJ & $"$ & 32.45 & 309 & 242 & $3.81 \mathrm{E}-13$ & 7.21 & 281 & 20 \\
\hline Dehane-2 & DEHR & $"$ & 55.55 & 307 & 1230 & $7.25 \mathrm{E}-13$ & 4.34 & 310 & 13 \\
\hline \multicolumn{10}{|c|}{ Sanaga river basin } \\
\hline Ebebda-1 & MBAM & Mbam & 38.11 & 307 & 1218 & $4.93 \mathrm{E}-13$ & 4.34 & 307 & 13 \\
\hline Ebebda-2 & SANA & Sanaga & 43.84 & 306 & 1230 & $5.76 \mathrm{E}-13$ & 4.47 & 311 & 14 \\
\hline
\end{tabular}

Table 4. Cosmogenic ${ }^{10} \mathrm{Be}$ analytical data. $\mathrm{N}^{10} \mathrm{Be}$ : Concentration of ${ }^{10} \mathrm{Be}$ in the sample $\left[{ }^{10} \mathrm{Be}\right]$ is the concentration in the sample and +/= its uncertainty.

The concentration of ${ }^{10} \mathrm{Be}, \mathrm{C}^{10} \mathrm{Be}$ in the river sand samples allows us to estimate the mean denudation rate $\varepsilon$ in the catchment upstream from the sampling site (e.g. Brown 
et al., 1995; Granger et al., 1996). The recorded denudation rate $\varepsilon$ corresponds to the topsoil, because the typical penetration depth of cosmic rays is less than $1 \mathrm{~m}$ (this problem is addressed in the discussion). We assume that $\mathrm{C}^{10} \mathrm{Be}$ corresponds to a secular equilibrium between the loss by erosion and the gain by production on the Earth's surface. The mean catchment denudation rate $\varepsilon$ is calculated using Equation 2.

\section{Equation 2}

$$
\epsilon=\frac{\Lambda_{n} P_{n}}{\rho C^{10} B e}+\frac{\Lambda_{\mu s} P_{\mu s}}{\rho C^{10} B e}+\frac{\Lambda_{\mu f} P_{\mu f}}{\rho C^{10} B e}
$$

where $P$ is the average catchment production rate, $\rho$ is the rock density $\left(2.7 \mathrm{~g} / \mathrm{cm}^{3}\right.$ for bedrock), $\Lambda$ is the attenuation length depending on which secondary particle is producing ${ }^{10} \mathrm{Be}$ in the mineral $\left(\Lambda_{\mathrm{n}}=160 \mathrm{~g} / \mathrm{cm}^{2}\right.$ for neutrons, $\Lambda_{\mu \mathrm{s}}=1500 \mathrm{~g} / \mathrm{cm}^{2}$ for negative muons and $\Lambda_{\mu \mathrm{f}}=5300 \mathrm{~g} / \mathrm{cm}^{2}$ for fast muons; (Braucher et al., 2003)). Using the new muon contribution estimate of Braucher et al. (2013) (with an attenuation length of $4300 \mathrm{~g} / \mathrm{cm}^{2}$ for muons without distinguishing between negative and fast muons), the erosion rates are $0.6 \%$ smaller. The ${ }^{10} \mathrm{Be}$ radioactive decay is usually neglected as proposed by previous works (Brown et al., 1995; Granger et al., 1996; von Blanckenburg, 2005). Introducing radioactive decay allows for the formal calculation of $\varepsilon$, but it is possible to show that introducing radioactive decay would decrease $\varepsilon$ by no more than $\lambda \rho / \Lambda_{n} \sim 0.3 \mathrm{~m} / \mathrm{Ma}$, which is very low in comparison with the erosion rates calculated below (Brown et al., 1995; Granger et al., 1996).

The above description is valid if all denudation comes from material that is eroded near the Earth's surface (the depth is smaller than the attenuation length). For a thick regolith like in Cameroon, the method needs to be modified or considered with regards to two specific points. (1) The density evolves from bedrock to topsoil. Denudation fluxes ( $F, \mathrm{~kg} / \mathrm{m} 3 / \mathrm{yr}$ ) can be written without taking the density into account (Equation 3 ).

Equation 3

$$
F\left[\mathrm{~kg} / \mathrm{m}^{2} / \mathrm{yr}\right]=\varepsilon[\mathrm{cm} / \mathrm{yr}] \times \rho\left[\mathrm{g} / \mathrm{cm}^{3}\right] \times 10=\frac{\Lambda_{n} P_{n}}{C^{10} B e}+\frac{\Lambda_{\mu s} P_{\mu s}}{C^{10} B e}+\frac{\Lambda_{\mu f} P_{\mu f}}{C^{10} B e}
$$

Thus we treat denudation as a flux, rather than as a vertical velocity. (2) The representativeness of the $\mathrm{CRN}$ concentration in quartz goes through the evaluation of quartz enrichment from bedrock to soil; as such it is commonly assumed that quartz is essentially insoluble and only removed by physical erosion, while the denudation of the bulk soil occurs by both physical erosion and chemical weathering (text inspired by Granger and Riebe, 2007; also see Dixon et al., 2009; Hewawasam et al., 2013; Riebe et al., 2003). This enrichment is calculated through the CEF (chemical erosion factor), defined by Equation 4:

\section{Equation 4}

$$
C E F=\operatorname{Rspr}\left(\operatorname{RSS}\left(1-e^{-\rho_{S} h_{S}} \Lambda\right)+e^{-\rho_{S} h_{S} / \Lambda}\right)
$$

where $R$ spr and $R s s$ are the concentration ratios for an immobile element between saprolite and rock and between soil and saprolite, respectively; $\rho_{s}$ and $h_{s}$ are the soil density and thickness (Riebe and Granger, 2013). In the literature, the simplified expression $C E F \sim R s r$ (Rsr is an immobile element concentration ratio between soil and rock) can also be found (e.g., Dixon et al., 2009; Hewawasam et al., 2013). We use the information collected around the Nsimi watershed (pits 1 L6 and IL5, Braun et al., 2005, 2012), expected to be representative of the Nyong watershed and at the Goyoum site (pits 319 and 341, Braun et al., 1998) located in the Sanaga catchment. We 
selected the immobile elements $\mathrm{Zr}$ and $\mathrm{Th}$ and found similar values for the two CEF evaluations: CEF 3.2 \pm 1 (Nsimi) and CEF 3.3 \pm 0.6 (Goyoum); thus in the following we choose a value of $3.2 \pm 1$ as representative for hillslopes. In alluvial valleys, the CEF may be lower, as suggested by chemical analyses of pit 313 at the Goyoum site (CEF 2.3 \pm 1.3 , Braun et al., 1998).

\section{Results}

\subsection{Physical characteristics of the river basins}

The Nyong River catchment can be divided into two parts. Upstream, it flows on the South Cameroon Plateau ( 650 m, Figure 2), where the slope is low at $0.05 \mathrm{~m} / \mathrm{m}$. At Olama the slope is approximately $0.015 \%$; but the values are higher for the upper basin $(0.11 \%$ at Ayos) and for the stations on the tributaries (0.1 to $1.3 \%)$. Between the OLAM and ESE stations, the river crosses the plateau edge (Figure 2), but the average slope remains very gentle on the order of $0.5 \%$ (the vertical elevation seen in the profile in Figure 2 is exaggerated by a factor of $\sim 1000$ ). This may result from the resolution and precision of the SRTM DEM. Here, the slope is low and the data is likely dominated by the noise on the SRTM dataset.
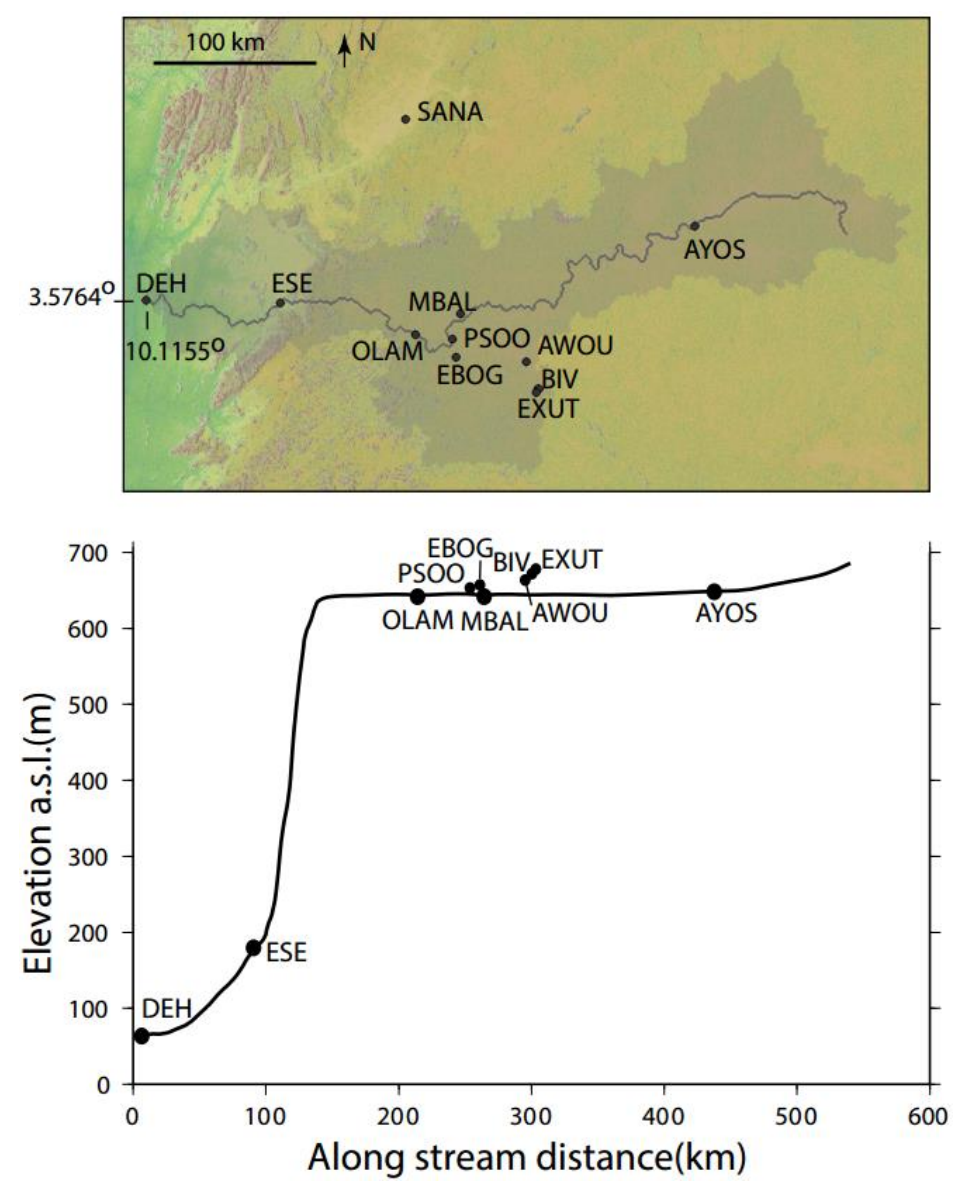

Figure 2. Map and longstream profile of the Nyong River catchment, showing the sampling stations. Large dots correspond to stations along the Nyong main stream; small dots are locations on the studied tributary. All the stations except DEH and ESE are located on the South Cameroon Plateau. The profile was smoothed using a $5 \mathrm{~km}$ sliding window. 


\subsection{Pre-anthropogenic denudation rates $\left({ }^{10} \mathrm{Be}\right)$}

\begin{tabular}{|c|c|c|c|c|c|c|c|c|c|c|c|c|c|c|c|c|c|c|}
\hline Station & Code & River & $\begin{array}{l}\mathrm{P} 10 \mathrm{Be} \\
\mathrm{at} / \mathrm{g} / \mathrm{a}\end{array}$ & $\begin{array}{l}\text { E10Be } \\
\mathrm{mm} / \mathrm{kyr}\end{array}$ & $\pm \sigma$ & $\begin{array}{c}\text { E10Be_c } \\
\mathrm{mm} / \mathrm{kyr}\end{array}$ & $\pm \sigma$ & $\begin{array}{c}\text { E10Be_c } \\
\mathrm{t} / \mathrm{km}^{2} / \mathrm{yr}\end{array}$ & $\pm \sigma$ & $\begin{array}{c}\text { T10Be } \\
\text { kyr }\end{array}$ & $\begin{array}{c}\text { TSS } \\
\mathrm{t} / \mathrm{km}^{2} / \mathrm{yr}\end{array}$ & $\begin{array}{l}\text { Erosion } \\
\text { rate } \\
\mathrm{mm} / \mathrm{kyr}\end{array}$ & $\begin{array}{c}\text { TDS } \\
\text { t/km²/yr }\end{array}$ & $\begin{array}{l}\mathrm{Si}(\mathrm{OH})_{4} \\
\mathrm{t} / \mathrm{km}^{2} / \mathrm{yr}\end{array}$ & $\begin{array}{c}\text { CWR } \\
\mathrm{mm} / \mathrm{kyr}\end{array}$ & $\begin{array}{c}\text { DOC } \\
\mathrm{t} / \mathrm{km}^{2} / \mathrm{yr}\end{array}$ & $\begin{array}{c}\text { Contemp- } \\
\text { orary } \\
\text { denudation } \\
\text { mm/kyr }\end{array}$ & $\begin{array}{c}\text { Chem. } \\
\text { Denud. } \\
\text { Prop. } \\
\text { \% }\end{array}$ \\
\hline \multicolumn{19}{|c|}{ Nyong river basin } \\
\hline Ayos & AYOS & Nyong & 4.601 & 2.72 & 0.42 & 8.69 & 3.04 & 23.47 & 8.96 & 221 & & & & & & & & \\
\hline $\operatorname{Nsimi}\left({ }^{*}\right)$ & EXUT & Mengong & 4.610 & 2.21 & 0.34 & 7.06 & 2.46 & 19.06 & 7.27 & 272 & 3.38 & 2.60 & 5.12 & 3.20 & 2.86 & 4.90 & 5.46 & 60.3 \\
\hline Zoulabot-1 & BIVB & Bivesse & 4.080 & 1.50 & 0.23 & 4.82 & 1.68 & 13.00 & 4.95 & 399 & & & & & & & & \\
\hline Zoulabot-2 & BIVG & $"$ & 4.080 & 1.68 & 0.26 & 5.36 & 1.87 & 14.48 & 5.52 & 358 & & & & & & & & \\
\hline Messam(*) & AWOU & Awout & 4.589 & 2.14 & 0.33 & 6.86 & 2.39 & 18.52 & 7.06 & 280 & 5.23 & 4.02 & 7.74 & 5.15 & 4.60 & 8.86 & 8.62 & 59.7 \\
\hline Pont $\mathrm{So}^{\prime} \mathrm{O}\left({ }^{*}\right)$ & PSOO & So'o & 4.266 & 2.52 & 0.39 & 8.08 & 2.82 & 21.81 & 8.32 & 238 & 7.56 & 5.81 & 8.15 & 5.37 & 4.80 & 6.49 & 10.62 & 51.9 \\
\hline Ebogo & EBOG & Nyong & 4.495 & 3.82 & 0.60 & 12.24 & 4.28 & 33.04 & 12.62 & 157 & & & & & & & & \\
\hline Mbalmayo $\left({ }^{*}\right)$ & MBAL & $"$ & 4.573 & 4.18 & 0.65 & 13.37 & 4.67 & 36.10 & 13.79 & 144 & 4.60 & 3.54 & 6.73 & 3.30 & 2.95 & 5.04 & 6.48 & 59.4 \\
\hline Olama $\left({ }^{*}\right)$ & OLAM & $"$ & 4.545 & 3.62 & 0.57 & 11.59 & 4.05 & 31.31 & 11.95 & 166 & 5.44 & 4.18 & 7.54 & 3.93 & 3.51 & 5.43 & 7.69 & 58.1 \\
\hline Eseka-1 & ESEB & $"$ & 4.534 & 4.82 & 0.76 & 15.43 & 5.39 & 41.67 & 15.91 & 124 & & & & & & & & \\
\hline Eseka-2 & ESEJ & $"$ & 4.534 & 6.07 & 0.95 & 19.41 & 6.78 & 52.41 & 20.00 & 99 & & & & & & & & \\
\hline Dehane-1 & DEHJ & $"$ & 4.292 & 10.65 & 1.77 & 34.06 & 12.06 & 91.97 & 35.50 & 56 & & & & & & & & \\
\hline Dehane-2 & DEHR & $"$ & 4.292 & 9.67 & 1.51 & 30.95 & 10.81 & 83.57 & 31.90 & 62 & & & & & & & & \\
\hline \multicolumn{19}{|c|}{ Sanaga river basin } \\
\hline Ebebda-1 & MBAM & Mbam & 5.644 & 12.62 & 1.97 & 40.38 & 14.11 & 109.03 & 41.62 & 48 & 98.00 & 75.40 & 34.34 & 17.43 & 15.57 & 1.46 & 90.97 & 25.9 \\
\hline Ebebda-2 & SANA & Sanaga & 5.079 & 11.28 & 1.77 & 36.09 & 12.61 & 97.45 & 37.21 & 53 & 18.00 & 13.80 & 19.32 & 9.85 & 8.80 & 1.45 & 22.60 & 51.8 \\
\hline
\end{tabular}

Specific fluxes come from the ORE-BVET project fot the Nyong stations (years 2000-2011), from Ndam (1997) for the Mbam and the Sanaga (cycle 1995/96). Erosion rates are calcutated for a upper soil density of 1,3 .

Table 5. Comparison between short-term (gauging) and medium-term $\left({ }^{10} \mathrm{Be}\right)$ denudation rates. $\mathrm{P} 10 \mathrm{Be}$ is the catchment-averaged production of $10 \mathrm{Be}$. $\mathrm{E} 10 \mathrm{Be}$ and $\mathrm{E} 10 \mathrm{Be} \mathrm{C}$ are the raw and corrected (with $\mathrm{CEF}$ ) denudation rates from 10Be expressed in $\mathrm{mm} / \mathrm{kyr}$ and $\mathrm{t} / \mathrm{km}^{2} / \mathrm{yr}$. $\pm \sigma$ is the $1 \sigma$ uncertainty on the preceding column value. The contemporary denudation rate is the sum TDS and TSS. Chem. Denud. Prop. is the proportion of chemical denudation on total denudation.

The catchment pre-anthropogenic denudation rates obtained by ${ }^{10} \mathrm{Be}$ are expressed in both $\mathrm{mm} / \mathrm{ky}$ and $\mathrm{t} / \mathrm{km}^{2} / \mathrm{yr}$ and are presented in Table 5 . Once corrected for quartz enrichment, they range from 4.8 to $40.3 \mathrm{~mm} / \mathrm{kyr}\left(4.8-40.3 \mathrm{~m} / \mathrm{Ma}\right.$ or $13-109 \mathrm{t} / \mathrm{km}^{2} / \mathrm{yr}$ ), corresponding to relatively low denudation rates. These denudation rates are in the lower range of the worldwide dataset provided by Portenga and Bierman (2011). In three sites we collected two samples in different parts of the riverbed (Bivesse River at Zoulabot, Nyong River at Eseka and Nyong River at Dehane): the concentrations never differ by more than $20 \%$ (Table 4 ). In practice, this denudation rate is integrated over a "characteristic time", which is the time needed to erode a strip of rock for which the thickness is the attenuation length (we only consider this for the most efficient producing rays: neutrons). Consequently, the lowest denudation rates are integrated over the longest period of time. This period is calculated to be between 48 and 399 kyrs; it is often more than 100 kyrs implying that this denudation rate integrates both glacial and interglacial climates (Table 5).

In Figure 3, we plotted the ${ }^{10} \mathrm{Be}$-derived denudation rates as a function of the classically used geomorphic parameters: basin area and basin slope. Interestingly, and counter-intuitively, the denudation rate increases with the basin area while the two variables are expected to be independent. On the contrary, denudation is not clearly dependent on basin slope as observed elsewhere (Carretier et al., 2013). 


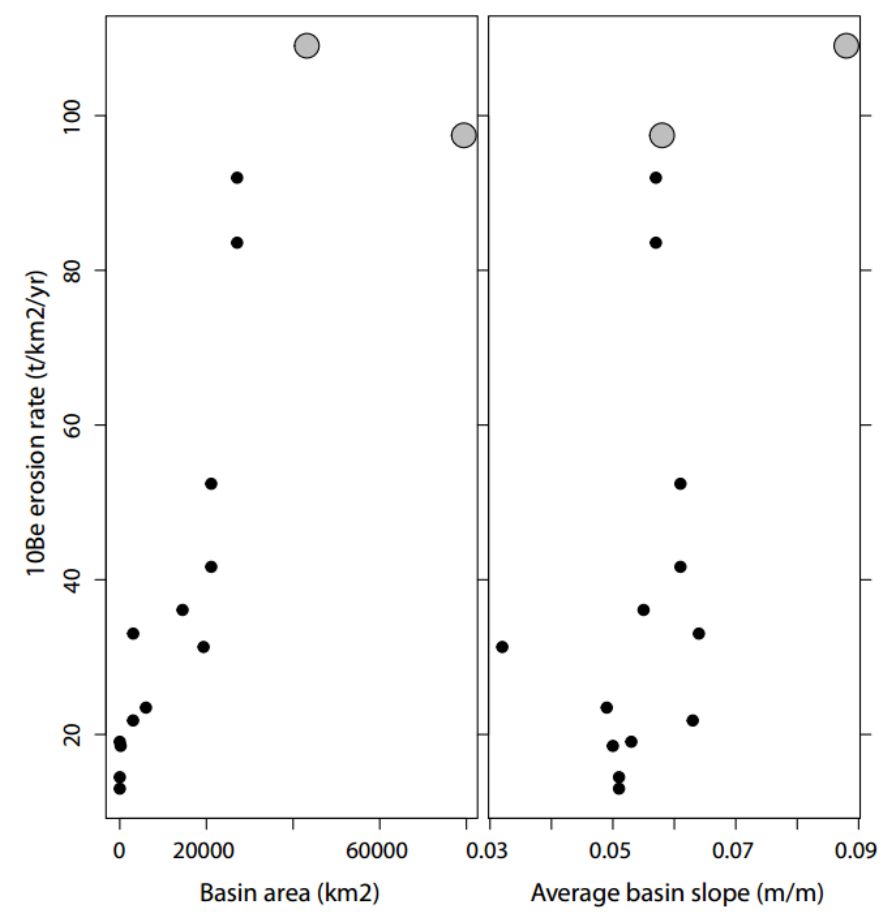

Figure 3. ${ }^{10} \mathrm{Be}$ denudation rates in function of catchment physical parameters: area, slope. The grey and bigger symbols are Mbam and Sanaga catchments.

\section{Discussion}

\subsection{Contemporary versus long-term denudation rates in South Cameroon}

The analyses presented here allow for the comparison of two time scales, from the decennial time scale (gauging) to several tens of kyrs $\left({ }^{10} \mathrm{Be}\right)$. The ${ }^{10} \mathrm{Be}$ time scale is smaller for higher denudation rates and varies from 50 kyrs (MBAM, SANA, DEHJ, DEHR) to more than 200 kyrs (AYOS, EXUT, BIVB, BIVG, AWOU and PSOO): as a consequence, our analyses encompass multiple glacial/interglacial cycles for the low denudation rate samples, while it only integrates over the last glacial period for MBAM, SANA, DEHJ and DEHR.

In our dataset, the smallest ${ }^{10} \mathrm{Be}$-derived denudation rates are observed for the smallest catchments, and Figure 3 indicates a simple relationship with the denudation rate that is proportional to the catchment area, at least up to $200,000 \mathrm{~km}^{2}$, i.e., for the Nyong catchment when it is only located on the South-Cameroon Plateau (the Eseka and Dehane stations are downslope from the plateau edge). The only exception is EBOG, for which the catchment is quite small $\left(3096 \mathrm{~km}^{2}\right)$ and the ${ }^{10} \mathrm{Be}$-derived denudation rate is quite large $\left(33.04 \mathrm{t} / \mathrm{km}^{2} / \mathrm{yr}\right)$. It should to be emphasized that the EBOG sampling point is located downstream from the confluence with the Mefou tributary which drains the urban and peri-urban area of Yaoundé city; this could explain the increase in sediment river load at that specific location.

The catchment mean denudation rate (in $\mathrm{m} / \mathrm{yr}$ or specific sediment yield in $\mathrm{t} / \mathrm{km}^{2} / \mathrm{yr}$ ) has been found to either decrease (e.g., Dedkov, 2004; Dendy and Bolton, 1976; Summerfield and Hulton, 1994; Syvitski and Milliman, 2007) or increase (e.g., Dedkov and Mozzherin, 1992) with the catchment area. Based on a synthesis of these works 
and numerical modelling, Birkinshaw and Bathurst (2006) concluded that a decrease mostly occurs in catchments dominated by hillslope erosion, whereas the reverse is observed in catchments where sediments are mainly produced by river bank erosion. These relationships may also be explained by a heterogeneous distribution of the erosive rainfall vegetation cover, natural or artificial sediment traps or land use (Birkinshaw and Bathurst, 2006 and references herein). In the Cameroon catchments, the forest-cover, which may limit sediment production, does not seem to decrease downstream, but the rainfall slightly increases downstream. In the Nyong River basin, there is a rainfall gradient with the Mean Annual Rainfall varying from $3000 \mathrm{~mm} / \mathrm{yr}$ seaward to $1600 \mathrm{~mm} / \mathrm{yr}$ inland (see the map in Fig. 7 provided in Braun et al., 2005). Thus, the observed positive relationship between the catchment mean erosion rate and area could be explained by either by a significant contribution of river bank erosion or by a downward increase in rainfall in this very gentle topography. In the case of the Nyong River, the river banks are invaded by thick floating vegetation mats which may limit bank failure and physical erosion. Downstream, the combination of increasing rainfall and passive margin scarp would increase the river erosion capacity.

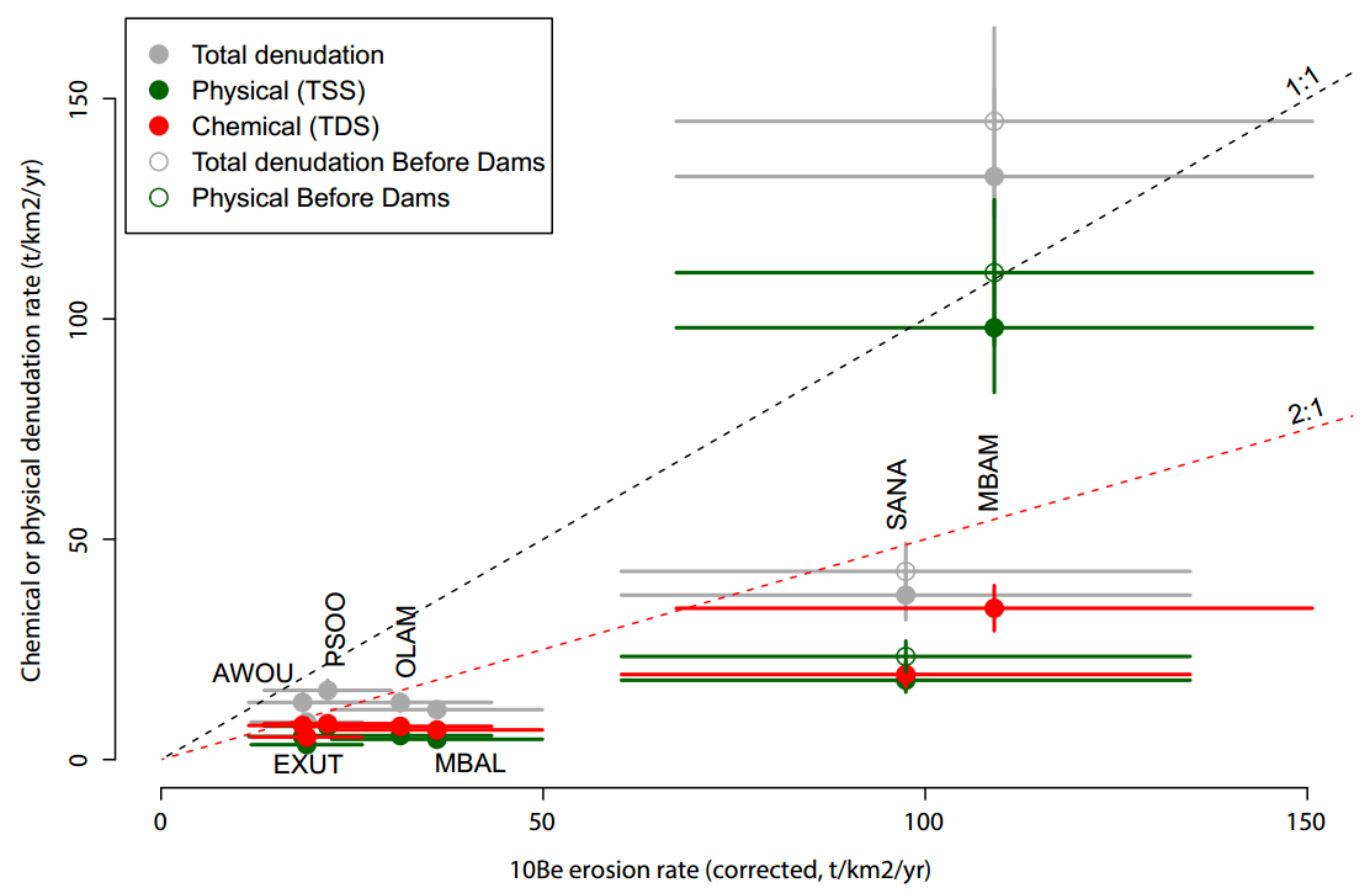

Figure 4. Contemporary vs ${ }^{10} \mathrm{Be}$ denudation rates. The contemporary denudation rate is the sum of TSS and TDS. Empty symbols represent the situation before dam building. Dashed lines are 1:1 and 2:1 lines.

Figure 4 displays the relationships between TSS, TDS and the ${ }^{10} \mathrm{Be}$-derived denudation rates. First, the Nyong basins display very low physical denudation rates that are lower than the chemical rates. For the Sanaga River, both of these rates are quite stable but when using the physical denudation rates recorded before dam building, TSS is higher than TDS. For the Mbam catchment, the physical denudation rate dominates $(\sim 75 \%)$ the total denudation rate. With regards to the total short-term denudation rate vs. the ${ }^{10} \mathrm{Be}$ denudation rates, most of the catchment points are below the 2:1 line in Figure 4: the short-term denudation rate is less than half the ${ }^{10} \mathrm{Be}$-derived denudation rate. The exact ratio is uncertain and this evaluation (the short-term rate is two times lower than the long-term denudation rate) must be taken with caution: as described above, these values have been corrected for quartz enrichment within the 
saprolite. This correction relies on two local pits and the uncertainty is likely to be $30 \%$ but may be up to $50 \%$ (see the Sampling and methodology section). Some catchment points, in contrast to the others, lie clearly above the 2:1 line. They correspond to catchments with either enhanced anthropogenic denudation (MBAM) or with anomalous solid discharge (AWOU and PSOO).

Our analysis sheds light on weathering processes and the saprolite equilibrium. If the weathering profile is at steady state, the weathering front propagates downward at the same velocity $(\mathrm{w})$ as the surface downwears $(\varepsilon)$. Physical denudation is $\varphi_{\varepsilon}=\varepsilon$. $\rho_{\mathrm{sp}}$, where $\rho_{\mathrm{sp}}$ is the saprolite density; similarly, the chemical denudation is $\varphi_{w}=w\left(\rho_{r}-\right.$ $\rho_{\mathrm{sp}}$ ), where $\rho_{\mathrm{sp}}$ is the unweathered rock density. As discussed aboven, the immobile elements $\mathrm{Zr}$ and Th show that the CEF $\sim 3.2 \pm 1$, implying that chemical and physical denudation accounts for $55-72 \%$ and $28-45 \%$ of the total denudation, respectively. This proportion is independently confirmed by the ratio between TDS and TSS (Table 5) indicating a usual chemical denudation proportion of $\sim 60 \%$ out of the total denudation. This proportion is lower for PSOO and SANA (52\%) and very low for MBAM (26\%), indicating a higher contribution of physical denudation; this confirms the observations made beforehand that these catchments are affected by anthropogenic disturbances.

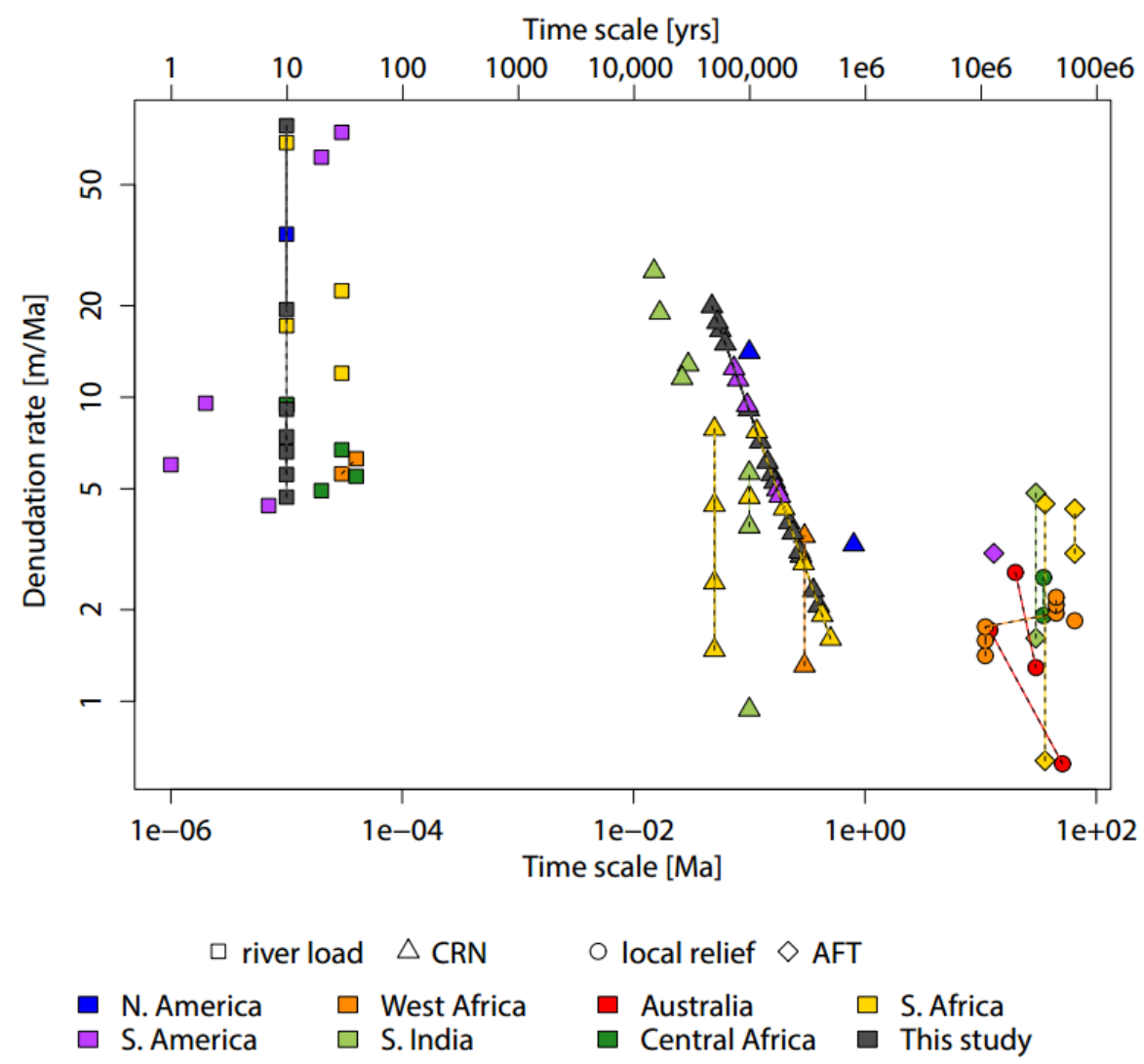

Figure 5. Cameroon denudation rates compared with other tropical cratonic denudation rates as compiled by Beauvais and Chardon (2013), updated with few recent studies (Bierman et al., 2014; Codilean et al., 2014; Mandal et al., 2015; Wittmann et al., 2010). Symbols indicate the methods used: river loads, CRN (cosmogenic radionuclides as ${ }^{10} \mathrm{Be}$ in this study), local relief (calculation of erosion of an ancient surface) and AFTA (Apatite Fission Track Analysis). Colors indicate the geographic location, grey symbols coming from the present dataset. Dashed lines connect samples various samples from the same area acquired with the same method. 


\subsection{Comparison of the tropical cratonic denudation rates}

Figure 5 shows various estimates of the cratonic denudation rates through different time scales. Gardner et al. (1987) proposed that the comparison of two time-dependent variables could introduce a bias when comparing various time-scales. They proposed a correction, which we used here following Beauvais and Chardon (2013). However, this correction accounts for a maximum difference of $50 \%$, and we prefer keeping the raw values in Figure 5. It appears from Figure 5 that our estimates fall within the ranges reported in the literature: $5-100 \mathrm{~m} / \mathrm{Ma}\left(10-200 \mathrm{t} / \mathrm{km}^{2} / \mathrm{yr}\right)$ for river load measurements and 1-20 m/Ma (2-50 t/ $\left.\mathrm{km}^{2} / \mathrm{yr}\right)$ for CRN. The long-term estimates are smaller than the millennial CRN estimates. In turn, the river loads indicate that the modern-day erosion rates are higher.

\section{Conclusion}

Denudation rates in Cameroon have been estimated by gauging data and cosmogenic radionuclides $\left(\mathrm{CRN},{ }^{10} \mathrm{Be}\right)$ along the Nyong catchment draining the South Cameroon Plateau as well as in two large rivers in northern Cameroun: the Sanaga River and Mbam River. The two methods have very different characteristic time scales: 10 yrs and 100 kyrs for gauging and CRN data, respectively.

Modern fluxes (from gauging data) range from 5 to $100 \mathrm{~m} / \mathrm{Ma}\left(10-200 \mathrm{t} / \mathrm{km}^{2} / \mathrm{yr}\right)$. The contribution of chemical denudation is typically $60 \%$ of the total denudation. When this ratio differs, anthropogenic effects may occur.

${ }^{10} \mathrm{Be}$ fluxes must be corrected as proposed by previous authors for sites with a thick regolith (saprolite + soil). These fluxes are slightly lower than modern-day fluxes, ranging from 4.8 to $40.3 \mathrm{~m} / \mathrm{Ma}$ or 13 to $109 \mathrm{t} / \mathrm{km}^{2} / \mathrm{yr}$; however, this difference is similar to that observed in other stable tropical areas. The data on the extent of chemical weathering from deep regolith weathering (used to derive the CEF) are confirmed by the data from the river loads (TDS/TSS ratio), suggesting that the relative importance of chemical weathering in the overall denudation of the landscape has remained relatively constant over time.

These fluxes are low and are typical of low-denudation areas with a tendency to increase with the catchment area.

\section{Ackowledgements}

In Cameroon, the multidisciplinary research carried on the Nsimi watershed began in 1994 under the control of IRD and IRGM-CRH (Institut de Recherche Géologique et Minière / Centre de Recherche Hydrologique, Yaoundé, Cameroon). Apart from the specific support from the French Institute of Research for Development (IRD), our project benefited from funding from the national programs PROSE/PEGI (Programme Sol Erosion/Programme Environnement Géosphère Intertropicale) and PNSE (Programme National Sol-Erosion) dedicated to a better understanding of the humid tropical ecosystems These programs were funded both by IRD and INSU / CNRS (Institut National des Sciences de l'Univers / Centre National de la Recherche Scientifique). The long term monitoring on Nsimi is supported by the project SO BVET (Service Observation Recherche en Environnement - Basins Versants Expérimentaux 
Tropicaux; http://bvet.omp.obs-mip.fr). We thank Mathieu Zang and Mathurin Amougou of the Nsimi village and Justin Nlozoa (IRGM-CRH) for the care that they took in setting up of the watershed and maintaining it. C. Lagane is thanked for the major element analyses at GET (Géoscience Environnement Toulouse). A. Beauvais kindly provided his cratonic denudation rate dataset; Y. Godderis is warmly thanked for discussions.

Sample for ${ }^{10} \mathrm{Be}$ were prepared in our lab hosted by 'service chimie' at GET, and were then measured at ASTER, Aix-en-Provence under the supervision of D. Bourlès, R. Braucher and L. Leanni who are warmly thanked for their support. This is also a LMI Copedim contribution.

We acknowledge 2 anonymous reviewers and the associate editor, J. Roering for valuable comments. Sara Mullin made the English editing.

\section{Bibliography}

Balthazar, V., Vanacker, V., Girma, A., Poesen, J., and Golla, S., 2013, Human impact on sediment fluxes within the Blue Nile and Atbara River basins: Geomorphology, v. 180-181, p. 231-241, doi: 10.1016/j.geomorph.2012.10.013.

Beauvais, A., and Chardon, D., 2013, Modes, tempo, and spatial variability of Cenozoic cratonic denudation: The West African example: Geochemistry, Geophysics, Geosystems, v. 14, p. 1590-1608, doi: 10.1002/ggge.20093.

Bellin, N., Vanacker, V., and De Baets, S., 2013, Anthropogenic and climatic impact on Holocene sediment dynamics in SE Spain: A review: Quaternary International, v. 308-309, p. 112-129, doi: 10.1016/j.quaint.2013.03.015.

Bellin, N., Vanacker, V., van Wesemael, B., Solé-Benet, A., and Bakker, M.M., 2011, Natural and anthropogenic controls on soil erosion in the Internal Betic Cordillera (southeast Spain): CATENA, v. 87, p. 190-200, doi: 10.1016/j.catena.2011.05.022.

Bierman, P.R., Coppersmith, R., Hanson, K., Neveling, J., Portenga, E.W., and Rood, D.H., 2014, A cosmogenic view of erosion, relief generation, and the age of faulting in southern Africa: GSA Today, v. 24, p. 4-11, doi: 10.1130/GSATG206A.1.

Bierman, P., Larsen, P., Clapp, E., and Clark, D., 1996, Refining estimates of $10 \mathrm{Be}$ and $26 \mathrm{Al}$ production rates: Radiocarbon, v. 38, p. 149.

Bird, M.I., Giresse, P., and Chivas, A.R., 1994, Effect of forest and savanna vegetation on the carbon-isotope composition of sediments from the Sanaga River, Cameroon: Limnology and oceanography, v. 39, p. 1845-1854.

Birkinshaw, S.J., and Bathurst, J.C., 2006, Model study of the relationship between sediment yield and river basin area: Earth Surface Processes and Landforms, v. 31, p. $750-761$, doi: $10.1002 /$ esp. 1291.

von Blanckenburg, F., 2005, The control mechanisms of erosion and weathering at basin scale from cosmogenic nuclides in river sediment: Earth And Planetary Science Letters, v. 237, p. 462-479.

von Blanckenburg, F., Belshaw, N.S., and O'Nions, R.K., 1996, Separation of 9Be and cosmogenic $10 \mathrm{Be}$ from environmental materials and SIMS isotope dilution analysis: Chemical Geology, v. 129, p. 93-99, doi: 10.1016/00092541(95)00157-3. 
von Blanckenburg, F., Bouchez, J., Ibarra, D.E., and Maher, K., 2015, Stable runoff and weathering fluxes into the oceans over Quaternary climate cycles: Nature Geoscience, v. 8, p. 538-542, doi: 10.1038/ngeo2452.

Braucher, R., Bourlès, D., Merchel, S., Vidal Romani, J., Fernadez-Mosquera, D., Marti, K., Léanni, L., Chauvet, F., Arnold, M., Aumaître, G., and Keddadouche, K., 2013, Determination of muon attenuation lengths in depth profiles from in situ produced cosmogenic nuclides: Nuclear Instruments and Methods in Physics Research Section B: Beam Interactions with Materials and Atoms, v. 294, p. 484-490, doi: 10.1016/j.nimb.2012.05.023.

Braucher, R., Brown, E.T., Bourles, D.L., and Colin, F., 2003, In situ produced Be-10 measurements at great depths: implications for production rates by fast muons: Earth And Planetary Science Letters, v. 211, p. 251-258.

Braun, J.-J., Marechal, J.-C., Riotte, J., Boeglin, J.-L., Bedimo Bedimo, J.-P., Ndam Ngoupayou, J.R., Nyeck, B., Robain, H., Sekhar, M., Audry, S., and Viers, J., 2012, Elemental weathering fluxes and saprolite production rate in a Central African lateritic terrain (Nsimi, South Cameroon): Geochimica et Cosmochimica Acta, v. 99, p. 243-270, doi: 10.1016/j.gca.2012.09.024.

Braun, J.-J., Ngoupayou, J.R.N., Viers, J., Dupre, B., Bedimo Bedimo, J.-P., Boeglin, J.-L., Robain, H., Nyeck, B., Freydier, R., Nkamdjou, L.S., Rouiller, J., and Muller, J.-P., 2005, Present weathering rates in a humid tropical watershed: Nsimi, South Cameroon: Geochimica et Cosmochimica Acta Acta / Geochimica et Cosmochimica Acta Acta; Geochimica et Cosmochimica Acta Acta (England); Geochimica et Cosmochimica Acta Acta, v. 69, p. 357-387, doi: 10.1016/J.GCA.2004.06.022.

Braun, J.-J., Viers, J., Dupré, B., Polve, M., Ndam, J., and Muller, J.-P., 1998, Solid/Liquid REE Fractionation in the Lateritic System of Goyoum, East Cameroon: The Implication for the Present Dynamics of the Soil Covers of the Humid Tropical Regions: Geochimica et Cosmochimica Acta, v. 62, p. 273299, doi: 10.1016/S0016-7037(97)00344-X.

Brown, E.T., Stallard, R.F., Larsen, M.C., Raisbeck, G.M., and Yiou, F., 1995, Denudation rates determined from the accumulation of in situ-produced $10 \mathrm{Be}$ in the luquillo experimental forest, puerto rico: Earth and Planetary Science Letters, v. 129, p. 193.

Carretier, S., Goddéris, Y., Delannoy, T., and Rouby, D., 2014, Mean bedrock-tosaprolite conversion and erosion rates during mountain growth and decline: Geomorphology, v. 209, p. 39-52, doi: 10.1016/j.geomorph.2013.11.025.

Carretier, S., Regard, V., Vassallo, R., Aguilar, G., Martinod, J., Riquelme, R., Pepin, E., Charrier, R., Hérail, G., Farías, M., Guyot, J.-L., Vargas, G., and Lagane, C., 2013, Slope and climate variability control of erosion in the Andes of central Chile: Geology, v. 41, p. 195-198, doi: 10.1130/G33735.1.

Chadwick, O.A., Roering, J.J., Heimsath, A.M., Levick, S.R., Asner, G.P., and Khomo, L., 2013, Shaping post-orogenic landscapes by climate and chemical weathering: Geology, v. 41, p. 1171-1174, doi: 10.1130/G34721.1.

Codilean, A.T., Fenton, C.R., Fabel, D., Bishop, P., and Xu, S., 2014, Discordance between cosmogenic nuclide concentrations in amalgamated sands and individual fluvial pebbles in an arid zone catchment: Quaternary Geochronology, v. 19, p. 173-180, doi: 10.1016/j.quageo.2012.04.007.

Conrad, C.P., and Husson, L., 2009, Influence of dynamic topography on sea level and its rate of change: Lithosphere, v. 1, p. 110-120, doi: 10.1130/L32.1. 
Covault, J.A., Craddock, W.H., Romans, B.W., Fildani, A., and Gosai, M., 2013, Spatial and Temporal Variations in Landscape Evolution: Historic and LongerTerm Sediment Flux through Global Catchments: The Journal of Geology, v. 121 , p. 35-56, doi: $10.1086 / 668680$.

Dedkov, A., 2004, The relationship between sediment yield and drainage basin area, in Sediment Transfer throngh the Fluvial System, IAHS Publication 288, p. 197-204.

Dedkov, A., and Mozzherin, V.I., 1992, The relationship between sediment yield and drainage basin area, in Erosion and sediment yield in mountain areas of the World, IAHS Publication 209, p. 29-36.

Dendy, F.E., and Bolton, G.C., 1976, Sediment yield-runoff-drainage area relationships in the United States.: Journal of Soil and Water Conservation, v. 31, p. 264-266.

Dixon, J.L., Heimsath, A.M., and Amundson, R., 2009, The critical role of climate and saprolite weathering in landscape evolution: Earth Surface Processes and Landforms, v. 34, p. 1507-1521, doi: 10.1002/esp.1836.

Dubreuil, P., Guiscafré, J., Nouvelot, J.-F., and Olivry, J.-C., 1975, Le Bassin de la rivière Sanaga: ORSTOM Monographies Hydrologiques, (X)-350 p. p., http://www.documentation.ird.fr/hor/fdi:04349 (accessed November 2014).

Gaillardet, J., Dupré, B., Louvat, P., and Allègre, C.J., 1999, Global silicate weathering and $\mathrm{CO} 2$ consumption rates deduced from the chemistry of large rivers: Chemical Geology, v. 159, p. 3-30, doi: 10.1016/S00092541(99)00031-5.

Gran, G., 1952, Determination of the equivalence point in potentiometric titrations. Part II: Analyst, v. 77, p. 661-671, doi: 10.1039/AN9527700661.

Granger, D.E., Kirchner, J.W., and Finkel, R.C., 1996, Spatially averaged long-term erosion rates measured from in situ-produced cosmogenic nuclides in alluvial sediment: Journal of Geology, v. 104, p. 249-257, doi: 10.1086/629823.

Granger, D.E., and Riebe, C.S., 2007, Cosmogenic Nuclides in Weathering and Erosion, in Treatise on Geochemistry, Volume 5: Surface and Ground Water, Weathering, and Soils, Drever, J.I. (Ed), Elsevier, London.

Guillocheau, F., Chelalou, R., Linol, B., Dauteuil, O., Robin, C., Mvondo, F., Callet, Y., and Colin, J.-P., 2015, Cenozoic Landscape Evolution in and Around the Congo Basin: Constraints from Sediments and Planation Surfaces, in Geology and Resource Potential of the Congo Basin (de Wit, M., Guillocheau, F., de WIt M.C.J., Springer, Regional Geology Reviews XLII, p. 271-313.

Hewawasam, T., Blanckenburg, F. von, Schaller, M., and Kubik, P., 2003, Increase of human over natural erosion rates in tropical highlands constrained by cosmogenic nuclides: Geology, v. 31, p. 597-600, doi: 10.1130/00917613(2003)031<0597:IOHONE>2.0.CO;2.

Hewawasam, T., von Blanckenburg, F., Bouchez, J., Dixon, J.L., Schuessler, J.A., and Maekeler, R., 2013, Slow advance of the weathering front during deep, supply-limited saprolite formation in the tropical Highlands of Sri Lanka: Geochimica et Cosmochimica Acta, v. 118, p. 202-230, doi: 10.1016/j.gca.2013.05.006.

Kirchner, J.W., Finkel, R.C., Riebe, C.S., Granger, D.E., Clayton, J.L., King, J.G., and Megahan, W.F., 2001, Mountain erosion over 10 yr, 10 k.y., and 10 m.y. time scales: Geology, v. 29, p. 591-594.

Lienou, G., Mahe, G., Olivry, J.-C., Naah, E., Servat, E., Sigha-Nkamdjou, L., Sighomnou, D., Ngoupayou, J.N., Ekodeck, G.E., and Paturel, J.E., 2005, 
Régimes des flux des matières solides en suspension au Cameroun: revue et synthèse à l'échelle des principaux écosystèmes; diversité climatique et actions anthropiques / Regimes of suspended sediment flux in Cameroon: review and synthesis for the main ecosystems; climatic diversity and anthropogenic activities: Hydrological Sciences Journal, v. 50, p. null-123, doi: 10.1623/hysj.50.1.111.56329.

Mandal, S.K., Lupker, M., Burg, J.-P., Valla, P.G., Haghipour, N., and Christl, M., 2015 , Spatial variability of $10 \mathrm{Be}$-derived erosion rates across the southern Peninsular Indian escarpment: A key to landscape evolution across passive margins: Earth and Planetary Science Letters, v. 425, p. 154-167, doi: 10.1016/j.epsl.2015.05.050.

Maneux, E., 1998, Erosion mécanique des sols et transports fluviaux de matières en suspension : application des systèmes d'information géographique dans les bassins versants de l'Adour, de la Dordogne et de la Garonne [Ph.D Thesis]: Bordeaux 1, $252 \mathrm{p}$.

Migoń, P., and Lidmar-Bergström, K., 2001, Weathering mantles and their significance for geomorphological evolution of central and northern Europe since the Mesozoic: Earth-Science Reviews, v. 56, p. 285-324, doi: 10.1016/S0012-8252(01)00068-X.

Millot, R., Gaillardet, J., Dupré, B., and Allègre, C.J., 2002, The global control of silicate weathering rates and the coupling with physical erosion: new insights from rivers of the Canadian Shield: Earth and Planetary Science Letters, $v$. 196, p. 83-98, doi: 10.1016/S0012-821X(01)00599-4.

Monod, B., Regard, V., Carcone, J., Wyns, R., and Christophoul, F., Accepted, Postorogenic planar paleosurfaces of the central Pyrenees: weathering and neotectonic records: Comptes Rendus Geoscience, https://hal.archivesouvertes.fr/hal-01212752/ (accessed December 2015).

Ndam Ngoupayou, J.-R., 1997, Bilans hydrogeochimiques sous foret tropicale humide en afrique : du bassin experimental de Nsmi-Zoetele aux reseaux hydrographiques du Nyong et de la Sanaga au sud-Cameroun.

Hydrogeochemical budgets in the humid tropical forest of Africa : from the elementary watershed of Nsimi-Zoetele to Nyong ang Sanaga basins in South Cameroon [PhD Thesis]: Univ. Paris VI, 253 p., http://cat.inist.fr/?aModele=afficheN\&cpsidt=189086 (accessed November 2014).

Ndam Ngoupayou, J.R., Dzana, J.G., Kpoumie, A., Ghogomu, R.T., Takounjou, A.F., Braun, J.J., and Ekodeck, G.E., 2014, Present-day sediment dynamics of the sanaga catchment (Cameroon): from the total suspended sediment (TSS) to erosion balance: Hydrological Sciences Journal, v. 0, p. null, doi: 10.1080/02626667.2014.968572.

de Oliveira Carmo, I., and Vasconcelos, P.M., 2006, 40Ar / 39Ar geochronology constraints on late miocene weathering rates in Minas Gerais, Brazil: Earth and Planetary Science Letters, v. 241, p. 80-94, doi: 10.1016/j.epsl.2005.09.056.

Olivry, J.-C., 1986, Fleuves et rivières du Cameroun: Paris, ORSTOM, Monographies Hydrologiques 9, http://www.documentation.ird.fr/hor/fdi:25393 (accessed November 2014).

Olivry, J.-C., Bricquet, J.P., Thiébaux, J.P., and Sigha, N., 1988, Transport de matières sur les grands fleuves des régions intertropicales: les premiers résultats des mesures de flux particulaires sur le bassin du fleuve Congo, in 
Sediment Budgets, IAHS Publ. 174, Bordas M.P. \& Walling D.E. (eds.), p. 509-521.

Portenga, E.W., and Bierman, P.R., 2011, Understanding Earth's eroding surface with 10Be: GSA Today, v. 21, p. 4-10, doi: 10.1130/G111A.1.

Raymo, M.E., Ruddiman, W.F., and Froelich, P.N., 1988, Influence of late Cenozoic mountain building on ocean geochemical cycles: Geology, v. 16, p. 649-653, doi: 10.1130/0091-7613(1988)016<0649:IOLCMB>2.3.CO;2.

Regnoult, J.-M., 1986, Synthèse géologique du Cameroun:.

Retallack, G.J., 2010, Lateritization and Bauxitization Events: Economic Geology, v. 105, p. 655-667, doi: 10.2113/gsecongeo.105.3.655.

Riebe, C.S., and Granger, D.E., 2013, Quantifying effects of deep and near-surface chemical erosion on cosmogenic nuclides in soils, saprolite, and sediment: Earth Surface Processes and Landforms, v. 38, p. 523-533, doi: 10.1002/esp.3339.

Riebe, C.S., Kirchner, J.W., and Finkel, R.C., 2003, Long-term rates of chemical weathering and physical erosion from cosmogenic nuclides and geochemical mass balance: Geochimica et Cosmochimica Acta, v. 67, p. 4411-4427, doi: 10.1016/S0016-7037(03)00382-X.

Santoir, C., and Bopda, A., 1995, Atlas régional Sud-Cameroun:, http://cat.inist.fr/?aModele=afficheN\&cpsidt=109345 (accessed November 2014).

Schaller, M., von Blanckenburg, F., Hovius, N., and Kubik, P.W., 2001, Large-scale erosion rates from in situ-produced cosmogenic nuclides in European river sediments: Earth And Planetary Science Letters, v. 188, p. 441-458.

Ségalen, P., 1967, Les sols et la géomorphologie du Cameroun: Cahiers ORSTOM.Série Pédologie, v. 5, p. 137-187.

Summerfield, M.A., and Hulton, N.J., 1994, Natural controls of fluvial denudation rates in major world drainage basins: Journal of Geophysical Research: Solid Earth, v. 99, p. 13871-13883, doi: 10.1029/94JB00715.

Syvitski, J.P.M., and Milliman, J.D., 2007, Geology, Geography, and Humans Battle for Dominance over the Delivery of Fluvial Sediment to the Coastal Ocean: The Journal of Geology, v. 115, p. 1-19, doi: 10.1086/509246.

Syvitski, J.P.M., Vörösmarty, C.J., Kettner, A.J., and Green, P., 2005, Impact of Humans on the Flux of Terrestrial Sediment to the Global Coastal Ocean: Science, v. 308, p. 376-380, doi: 10.1126/science.1109454.

Tardy, Y., and Roquin, C., 1998, Derive des continents paleoclimats et altérations tropicales: $473 \mathrm{p}$.

Tomkins, K.M., Humphreys, G.S., Wilkinson, M.T., Fink, D., Hesse, P.P., Doerr, S.H., Shakesby, R.A., Wallbrink, P.J., and Blake, W.H., 2007, Contemporary versus long-term denudation along a passive plate margin: the role of extreme events: Earth Surface Processes and Landforms, v. 32, p. 1013-1031, doi: 10.1002/esp.1460.

Vanacker, V., von Blanckenburg, F., Hewawasam, T., and Kubik, P.W., 2007, Constraining landscape development of the Sri Lankan escarpment with cosmogenic nuclides in river sediment: Earth and Planetary Science Letters, v. 253, p. 402-414, doi: 10.1016/j.epsl.2006.11.003.

West, A.J., Galy, A., and Bickle, M., 2005, Tectonic and climatic controls on silicate weathering: Earth and Planetary Science Letters, v. 235, p. 211-228, doi: 10.1016/j.epsl.2005.03.020. 
Wilkinson, B.H., 2005, Humans as geologic agents: A deep-time perspective: Geology, v. 33, p. 161-164, doi: 10.1130/G21108.1.

Willenbring, J.K., and von Blanckenburg, F., 2010, Long-term stability of global erosion rates and weathering during late-Cenozoic cooling: Nature, v. 465, p. 211-214, doi: $10.1038 /$ nature09044.

Willenbring, J.K., Codilean, A.T., and McElroy, B., 2013, Earth is (mostly) flat: Apportionment of the flux of continental sediment over millennial time scales: Geology, p. G33918.1, doi: 10.1130/G33918.1.

Wittmann, H., Blanckenburg, F. von, Maurice, L., Guyot, J.-L., Filizola, N., and Kubik, P.W., 2010, Sediment production and delivery in the Amazon River basin quantified by in situ—produced cosmogenic nuclides and recent river loads: Geological Society of America Bulletin, p. B30317.1, doi: 10.1130/B30317.1. 